\title{
Ibn Qāḍī Shuhba (1377-1448): His Life and Historical Work
}

\author{
Tarek Sabraa
}

The Mamluk period witnessed a substantial number of scholarly families that appeared as dominant in many places in Egypt and Syria. This is due to several factors, such as the interest of sultans and amirs in promoting scholarship through the construction of madrasas and related infrastructures and the bestowal of money and gifts on scholars. ${ }^{1}$ One of the most important factors that played a role in securing the prominence of scholarly families is the inheritance of religious positions among the family members, in which some of them inherited their fathers' positions while they were still younger than eight or nine years of age. ${ }^{2}$ This played an important role in encouraging scholars to direct their children and grandchildren to study the Islamic sciences (e.g., jurisprudence, hadìth, theology, literature, etc.) in order to take over their positions after them. Among the families that were famous during the Mamluk era is the family of Ibn Qāọi Shuhba, which had a significant role and impact on the political and scientific life during the Ayyubid and Mamluk eras. Taqī al-Dīn Abū Bakr b. Qāḍ̄ Shuhba (1377-1448) is probably the most famous person in this family, and perhaps he is the one who played the most prominent role in its fame. Since, to my knowledge, this scholar has not received much attention in modern academia, this paper is meant to be the first of several ones to follow that will shed light on Ibn Qāḍī Shuhba, his significance as a scholar, and his work as a historian. ${ }^{3}$ In the current paper, I will give an overview of his historical

1 Al-Ṣafạī reminds us of how the sultan, the amirs, and their wives bestowed money on the head of the doctor Jamāl al-Dīn b. al-Maghribī and describes him as the saint of the century, al-Ṣafạīi, $A^{\prime} y \bar{a} n$ i, 55 .

2 See Berkey, formation 150-1. There are several examples, like Yūnus b. 'Alā' al-Dīn al-Subkī, who took over his father's post after his death at the age of eight. Yūnus died as a young man at the age of twelve, and his stepfather Ibn Hijji inherited his functions after his death. Ibn Hijjī, Tārīkh ii, 976.

3 There are no studies on Ibn Qāḍi Shuhba in Arabic and only a handful of smaller studies in English that touch upon Ibn Qādị̄ Shuhba and even less on his work. One work that focuses 
works as well as his life and family background. I believe that it is important to focus on his family's origins for several reasons, not just merely because he descends from a scholarly family, as I have mentioned above. It is also necessary to go back to his family's origin because it will help us to further understand Ibn Qāḍī Shuhba's historiographical approaches, since my main argument in this paper is that his particular background had an impact on his equally particular writing and understanding of history. Hence, the paper consists of two major parts: The first deals with the origins of Ibn Qâdị Shuhba's family and their history until his lifetime. The second part addresses his life and his scholarly work, focusing on his history writings.

\section{The Origins of the Ibn Qāọi Shuhba Family}

The roots of the family of Ibn Qādị Shuhba can be traced back to the tribe of Banū Asad ${ }^{4}$ from the branch of Banū Ghādira, ${ }^{5}$ which settled in Iraq during the era of 'Umar b. al-Khațtāb (634-44). ${ }^{6}$ In fact, many Arab tribes migrated from the Arabian Peninsula to Iraq and Syria during the reign of 'Umar (especially after the battle of Qādisiyya). ${ }^{7}$ Banū Ghādira was one of these tribes, as they migrated from Najd to Iraq and settled near Kufa and Karbala ${ }^{8}$ (and the place where they settled —al-Ghādiriyya—-was named after them). ${ }^{9}$ The historian Mușțafā Jawād mentions that the village of al-Ghādiriyya was established in the early days of Islam after the migration of Banū Asad to it. ${ }^{10}$ Certainly, those

on his work as a faqih:Jaques, Authority; the superficial and at times incorrect introduction to the hitherto edited parts of the Tarikkh Ibn Qä dị Shuhba by 'Adnān Darwīsh, published at the Ma'had al-'Ilmī al-Faransī li-l-Dirāsāt al-'Arabiyya; Reisman, in his article Holograph, studied some of the author's notes available at the Chester Beatty Library; and Massoud in his monograph Chronicles.

4 The tribe of Banū Asad is attributed to Asad b. Khuzayma b. Madraka b. Ilyās b. Muḍar al'Adnānī and Asad b. Khuzayma, who had five children, namely Dūdān b. Asad, Kāhel b. Asad, 'Amr b. Asad, Sa'b b. Asad, and Ḥulma b. Asad. Ibn Qāḍī Shuhba's family belongs to Dūdān b. Asad. See al-Balādhurī, Ansāb xi, 153 .

5 It is attributed to Ghāḍirab Mālik b. Tha'laba b. Dūdān b. Asad. See al-Balādhurī, Ansāa xi, 84 .

$6 \quad$ Al-Ṣafadī, Áyān v, 42; Jawād, Mawsūéat viii, 31.

7 Al-Ṭabarī, Tärīkh iii, 487.

8 Ibn Ḥabīb mentions that there are three different branches called al-Ghādiriyya in the tribes of Banū Khuza'a, Banū Asad, and Banū Qays. The family of the Ibn Qāộ̄ Shuhba is from al-Ghāẹiriyya of Banū Asad. Ibn Ḥabīb, Mukhtalaf 35.

9 Al-Ḥamawī, Mujjam iv, 183.

10 Jawād, Mawsūát viii, 31 . 


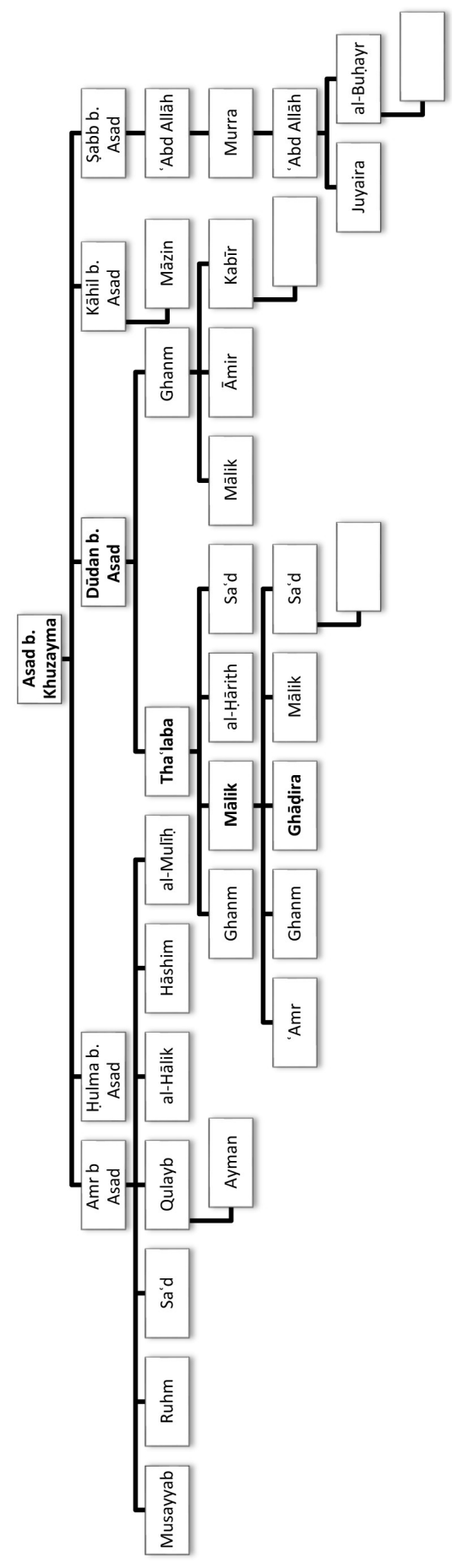

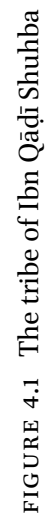


who settled there (or at least a significant number of them) were from the alGhādiriyya branch. Otherwise, the area would probably have been named after the main tribe (i.e., Banū Asad).

\subsection{The Intellectual and Political Doctrines of Banū Ghädira}

Arab tribes were split into two camps during the wars between 'Alī b. Abī Ṭālib and his opponents (656-61), in which some of them supported 'Alì while the others went against him. ${ }^{11}$ Broadly speaking, most of the tribes that settled in Iraq are said to have supported 'Alī b. Abī Ṭālib, while the tribes that settled in Greater Syria supported his main contender for the caliphate, Mu'āwiya b. Abī Sufyān. This is probably why many of the people who were inclined to accept the legitimacy of $\mathrm{Mu}$ 'àwiya migrated from Iraq to Syria. ${ }^{12}$ Among the tribes that supported 'Alī b. Abī Ṭālib was the tribe of Banū Asad, particularly the branch of al-Ghādiriyya, which supported him and his son al-Husayn intellectually and militarily. By intellectually I mean that the well-known scholars from alGhāẹiriyya (re)produced the texts/chronicles that supported and praised 'Alī b. Abì Țālib, and at the same time, they transmitted the chronicles that criticized Mu āwiya and delegitimized his rule.

A good example is that of Zirr b. Hubaysh al-Ghādirī al-Asadī, ${ }^{13}$ the famous scholar and companion of 'Alī b. Abī Țālib, and perhaps also one of his most fanatical supporters. This can be simply deduced from the fact that some historians gave Zirr b. Hubaysh the epithet of al-'Alawī. ${ }^{14}$ More importantly, he also supported 'Alī intellectually by transmitting narratives that praised 'Alī or demeaned Mu'āwiya b. Abī Sufyān. Al-Balādhurī, for instance, mentioned in his book Ansāb al-Ashrāf a hadìth transmitted by Zirr b. Hubaysh that 'Alī b. Abī Tâalib has said, "No one loves me except [a true] believer, and no one hates me except a hypocrite." ${ }^{15}$ Furthermore, al-Balādhurī stated that Zirr b. Hubaysh added after this narrative that "['Alī] is the most knowledgeable judge among the Muslims."'6 Ibn al-Maghāzilī also reported in his book Manāqib Alī (The virtues of 'Alī b. Abī Ṭâlib) two prophetic traditions transmitted by 'Āṣim b.

11 The most famous battle that took place between 'Alī and his opponents ('Á'isha, Ṭalha, al-Zubayr, Mu'āwiya b. Abī Sufyān, and 'Amr b. al-'̄̄s) is the war of Șiffīn.

12 Nașr b. Muzāḥim, Waq'it 146.

13 Zirr b. Hubaysh is a well-known scholar and a disciple of 'Alī b. Abī Ṭālib, which explains his hostility towards Mu'āwiya b. Abī Sufyān. Anyway, his scholarship was highly regarded in both Sunni and Shi'ite circles.

14 The historians who described him as al-'Alawī are: Ibn 'Asākir, Tärīkh xix, 29; al-Dhahabī, Tārīkh ii, 935; al-Mazzī, Tahdhīb ix, 338; Ibn Ḥajar, al-Ișāba ii, 633.

15 Al-Balādhurī, Ansāb ii, 97.

16 Ibid. 
Abī l-Nujūd al-Ghādirīi al-Asadīì (who is one of the most prominent transmitters of the Quranic readings) from Zirr b. Hubayșh and Abdallāh b. Mas'üd. In the former, the Prophet tells 'Alī, "your position to me is similar to Aaron's position to Moses"; ${ }^{18}$ in the latter, the hadīth says, "Fāțima has guarded her chastity therefore God forbade hellfire to accept her offspring." ${ }^{19}$

On the other hand, Zirr b. Hubayṣh transmitted narratives that attacked and criticized Mu'āwiya. For example, al-Balādhurī and Nasr b. Muzāḥim mentioned a hadìth narrated by Zirr b. Hubayṣh (who heard it from 'Abdallāh b. Mas'ūd) that states: "If anyone sees Mu'āwiya b. Abī Sufyān orating on a pulpit, [he must] beat his neck [with a sword]." ${ }^{20}$ These types of narratives were transmitted not only by Zirr b. Hubayṣh from the al-Ghāḍiriyya tribe but also 'Ạṣim b. Abī l-Nujūd al-Ghāọrī al-Asadī, a student of Zirr b. Ḥubayṣh, who transmitted the abovementioned hadìth calling for people to kill Mu'āwiya b. Abī Sufyān.

These texts show the tenacity of the remembrance of an unwavering stance of the scholars of Banū Ghāḍirain supporting 'Alī b. Abì Taalib and criticizing Mu'āwiya b. Abī Sufyān. Thus, we can say with certainty that Banū Ghāḍira is remembered as having a clear affiliation with 'Alī b. Abì Țälib's camp. This particular relation, which is imagined to have bound Banū Ghādira with 'Alī b. Abī Ṭālib, can also be seen in the story that 'Āṣim b. Abī l-Nujūd taughtexclusively — to his stepson and student, Ḥafṣ b. Sulaymān al-Ghāḍirī al-Asadī. While they were taught the Quranic reading of 'Alī b. Abī Țālib, his other students learned about a different Quranic reading, which had been transmitted by 'Abdallāh b. Mas'ūd.

During the early Islamic era, many scholars from Banū Ghādira are remembered as having engaged themselves in defending and supporting claims of Shi'i leadership. These include the likes of Abū 'Abdallāh Muhammad b. 'Abbās al-Ghāḍirī̄1 and his father Abū Muḥammad 'Abbās b. Īsā al-Ghāḍirī. ${ }^{22}$

Militarily, Banū Asad in general and Banū Ghāẹira in particular are traditionally portrayed as having supported 'Alī b. Abī Ṭālib and his son al-Ḥusayn in their wars against their opponents. In the battle of Șiffin (and the other battles fought by 'Alī b. Abī Ṭālib), for instance, most of Banū Asad are mentioned

\footnotetext{
17 'Āṣim b. Abī l-Nujūd al-Ghāẹirī al-Asadī, one of the famous narrators of the Quran, died in $127 / 745$.

18 Ibn al-Maghāzilī, Manāqib 83.

19 Ibid. 417.

20 Al-Balādhurī, Ansāb v, 13o; Nașr b. Muzāḥim, Waq it 216.

21 He is the muhaddith and Quranic interpreter Abū 'Abdallāh Muhammad b. 'Abbās b. 'Īsā al-Ghāọirī, died in the year 3oo/913. Al-Najāshī, Rijäl 326 .

22 He is the hạadìth specialist Abū Muhammad b. 'Abbās b. 'Isā al-Ghāḍirī. Al-Najashī, Rijāl 270 .
} 


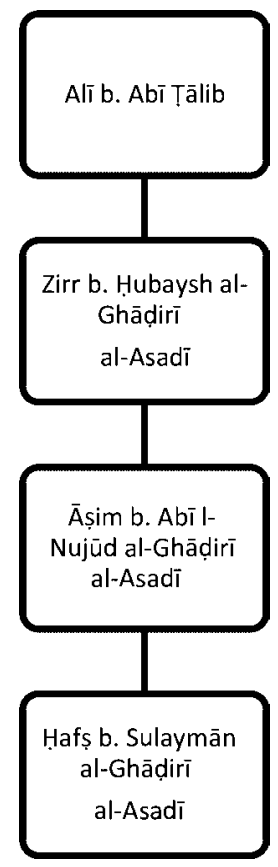

FIGURE 4.2

Transmission of the Quranic reading of 'Alī b. Abī Ṭālib

among his army, except Sammāk b. Makhrama al-Asadī23 and a small group of Banū Asad (consisting of almost 1oo people) who fled from Kufa to al-Raqqathe stronghold of Mu'āwiya's supporters to join the camp of Mu'āwiya. ${ }^{24}$

However, Banū Ghādira is not generally believed to have participated in al-Ḥusayn's army in his battle against Yazīd b. Mu'āwiya. This was most probably due to their limited number since the battle of Karbala (61/68o) occurred eleven years after the plague struck Kufa in the year 49/669. ${ }^{25}$ This plague had a quite high mortality rate, especially among Banū Ghādira, as most of the tribe is reported to have vanished a few years before the battle. ${ }^{26}$ Nonetheless, alHusayn b.'Ali must have been aware of the relation between his father and Banū Ghādira as this may well be why he chose the area of the village of al-

23 Sammāk b. Makhrama al-Asadī, one of the chiefs of Banū Asad. He had a major role in converting many persons of his tribe from supporting 'Alī b. Abī Ṭālib to Mu'āwiya b. Abī Sufyān's camp. Some historians mention that 7oo persons from Banū Asad moved from 'Alī's army to Mu'āwiya's army because of the incitement of Sammāk. Nașr b. Muzāhim, Waq'it 146; Ibn 'Asākir, Tārīkh xxii, 294.

24 Nașr b. Muzāhịim, Waq'it 146.

25 Ibn al-Jawzī, Muntazim v, 224.

26 Al-Mazzī, Tahdhïb v, 53. 
Ghādiriyya as a battleground for his war against the army of Yazīd. ${ }^{27}$ Noticeably, Banū Ghädira are remembered as the ones who buried the body of Husayn and his companions after their death in the battle. ${ }^{28}$ Examining these texts makes it clear that the members of Banū Ghādira were so-called proto-Shicites and supporters of 'Alī b. Abī Tâlib and the leadership of his family. ${ }^{29}$

\subsection{The Migration of Members from the Tribe of Banū Ghạdira to Greater Syria ${ }^{30}$}

The are several reasons behind the migration of Banū Ghāḍira from Kufa to Greater Syria during the first and second Islamic centuries, such as ideological factors, natural disasters, economic factors, and exile. Here I will briefly discuss these reasons.

27 Al-Dīnurī, $A k h b \bar{a} r 263$.

28 Al-Ṭabarī, Tärīkh v, 455.

29 Here we must discuss what Shi'ism meant throughout Islamic history, and the differ-

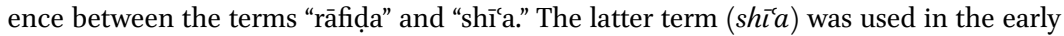
Islamic era to describe those who supported 'Alī b. Abī Ṭālib against his opponents. In this sense, using this term was not quite problematic in Sunni circles. For instance, many Sunni scholars (from early Islamic history till the Ayyubid era) were described as shica, like Ismācîl al-A`mash (d. 148/765), Abī Isḥāq al-Subayīì (d. 127/745), al-Ḥākim al-Naysabūrī (d. 349/96o), and many others. Noticeably, being Shicites (or described as ones) did not negatively influence the status of those scholars during this era. On the other hand, at the beginning of the Ayyubid era, the term shīa acquired a more political connotation, especially after the abolition of the Fatimid Caliphate in Egypt. The accusation of being Shicite then had a serious repercussion since it implicitly meant that the person was affiliated with the Fatimids in some way or another, and in many cases those persons who were accused of being Shi'ites ended up in jail. (See Ibn Wāṣil, Mufarrij ii, 276). In the Mamluk period, being described as Shicites, was not to some extent problematic as we can see that al-Ṣafadī and Ibn Qāḍi Shuhba mentioned some Shicite scholars in their books in a respectful manner (see al-Ṣafadī, Áyān i, 107; iv, 355; iv, 572; and Ibn Qāọī Shuhba, Tārīkh i, 594; iii, 484; iv, 211). As for the term "rāfiḍa," it always held a negative connotation in Sunni circles throughout Islamic history. This term was mainly used to describe persons who refused to accept the legitimacy of the first two caliphs, Abū Bakr and 'Umar. Therefore, any person accused of raf̣ was regarded as a heretic, and there were many cases during the Mamluk period in which people who were accused of being rāfị̂̄is were put on trial and executed (Ibn Kathīr, Ibn Hijjī, and Ibn Qāḍi Shuhba mentioned examples of this. See Ibn Kathīr, Bidāya, xviii, 965; Ibn Hijji, Tārīkh i, 254; Ibn Qāḍī Shuhba, Tārīkh i, 358; ii, 6o).

30 The Ghāḍiriyya members who settled in Syria were from the branches of Banū Asad (whose members settled in al-Raqqa, Ḥūrān, and Damascus) and Banū Qays (whose members settled in Hums). Ibn Mandah, Mustakhraj ii, 231; ii, 254, 551; Ibn Hajar, Iṣāba ii, 257. 


\subsubsection{The Ideological Factors}

The majority of the members from Banū Ghādira who migrated from Kufa to al-Raqqa may have held different ideologies than their fellow tribesmen. In general, Banū Ghādirira were loyal to 'Alī, as I have discussed above. Nonetheless, some of them, led by Sammāk b. Makhrama al-Asadī, ${ }^{31}$ appear to have been more inclined to support $\mathrm{Mu}$ 'āwiya, which prompted them to migrate from Kufa, the stronghold of the loyalists of 'Alī in 36/656, to al-Raqqa, which was predominantly inhabited by Muāwiya's supporters at the time.

We can actually confirm that some members from Banū Ghāọira or Banū Asad indeed migrated to al-Raqqa by checking their nisba. For instance, the nisba of one of the teachers of al-Balādhurī was al-Ghādirī al-Raqqī. ${ }^{32}$ Also, alQushayrī, in his history of al-Raqqa, mentions many scholars and poets from Banū Asad or Banū Ghāḍira who were from al-Raqqa. ${ }^{33}$

\subsubsection{Natural Disasters}

As mentioned, in the year 49/669, a major epidemic of plague ${ }^{34}$ broke out in Kufa and is reported to have caused the death of many people from Banū Ghādira. Therefore, some of them are said to have migrated from Kufa to the Levant to flee the plague. Among those who migrated from Kufa to Damascus seems to have been the aforementioned Zirr b. Hubaysh. ${ }^{35}$

\subsubsection{Economic Factors}

Trading opportunities clearly were another motive behind the migration from Kufa to Damascus for some of the members from Banū Ghādira. Of course, Damascus was the capital of the Umayyad Caliphate and the center of commerce until the second half of the second Islamic century. This made it the mecca of merchants at this period; the famous merchant 'Abada b. Abī Lubāba al-Asadī al-Ghāḍirī, ${ }^{36}$ like many other members of his tribe, reportedly moved there from Kufa.

\footnotetext{
$31 \quad$ Nașr b. Muzāḥim, Waq it 146.

32 Al-Balādhurī, Ansāb ii, 97.

33 Al-Qushayrī, Tārīkh 158, 173, 122, 11067.

34 Ibn al-Jawzī, Muntazzim v, 224.

35 Al-Mazzì, Tahdhīb v, 53.

36 He is the merchant 'Abada b. Abī Lubāba al-Asadī al-Ghāḍirī (d. ca. 127AH). See alDhahabī, Tārīkh iii, 459.
} 


\subsubsection{Exile}

Exile seems to have been another reason that led some of the members of al-Ghādiriyya's tribe to leave their homeland. An example of this is the poet al-Hakam b. 'Abadal al-Asadī al-Ghāẹirī̄, 37 who was forced to leave Kufa and settled in Damascus because of his exile by the anti-Umayyad ruler 'Abdallāh b. al-Zubayr in the course of the second civil war (68o-92). ${ }^{38}$

\subsection{The Family of Ibn Qā in the City of Shuhba}

It is not known exactly when the family of Ibn Qāḍi Shuhba settled in the village of Shuhba, in the region of Hawrān, close to today's Jordan border. One possible hypothesis is that they migrated from Kufa to Shuhba in two stages. The first stage must have been their migration from Kufa to al-Raqqa along with Sammāk b. Makhrama al-Asadī, who left due to his ideological disagreement with the rest of the tribe, as discussed above. The second stage represented their migration from al-Raqqa to the village of Shuhba, in which, meanwhile, the Banū Asad had centered. The migration of Ibn Qāḍī Shuhba's predecessors to Shuhba might be explained by their feeling of weakness in al-Raqqa where they must have settled far away from the rest of their tribe. As al-Qushayrī explains, until the Abbasid period, the Ghādiriyya branches who lived in al-Raqqa far from the rest of the tribe in the vicinities of Shuhba were unable to protect themselves from any aggression and they had to seek protection from the chiefs of some other tribes. ${ }^{39}$

The weakness of al-Ghāọiriyya and Banū Asad probably had a major impact on their decision to travel to the village of Shuhba, especially since they used to be a quite strong and influential tribe. Their choice of the village of Shuhba was perhaps also due to the presence of some of the branches of Banū Asad in this region, even before the emergence of Islam. The French historian René Dussaud has shown that there were some Arab tribes, including Banū Asad, in the village of Shuhba and its surroundings even before the emergence of Islam, as we can infer from the inscription found on the tombstone of the king of al-Hīra, Imru' al-Qays (d. 328). ${ }^{40}$ Noticeably, Ibn Qāọī Shuhba in 759/1358 also affirms that Banū Asad lived in this area, as he mentions that war had erupted

He is the poet al-Hakam b. 'Abadal al-Asadī al-Ghāḍirī. He died in Damascus during the reign of 'Abd al-Malik b. Marwān (686-705). See Ibn 'Asākir, Tārīkh xxvi, 15.

38 Ibn 'Asākir, Tārīkh xxvi, 15 .

39 Al-Qushayrī, Tārīkh, 68, 96, 105, 169, 174.

40 Dussaud, Arabes 34-5. 
between Banū Hilāl and Banū Asad near Shuhba and that there were many fatalities among the Banū Asad. ${ }^{41}$ This also suggests that some branches from Banū Asad lived in this area from (at least) 300 years before the emergence of Islam till the time of Ibn Qāḍi Shuhba.

\subsection{Ibn Qādì Shuhba's Family in the Ayyubid and Mamluk Eras}

The family of Ibn Qàdī Shuhba is regarded as one of the most important families who played an important role in intellectual life during the Ayyubid and Mamluk periods. During the Ayyubid period, their role was confined to the area of Shuhba and its surroundings. Their great grandfather, Jamāl al-Dīn, was a well-known and influential shaykh in Hawrān. ${ }^{42} \mathrm{He}$ was the first person in the family to pursue a scholarly career and be appointed as a judge. This allegedly happened after his travel to Baghdad in order to ask the Abbasid caliph to be assigned as the judge of the town of Shuhba. ${ }^{43,44}$ Thereafter, this position became hereditary among his family, as it was occupied by his son Sharaf alDīn Muhammad ${ }^{45}$ and later his grandson Najm al-Dīn 'Umar. Here, I will briefly speak about the role of Ibn Qādī Shuhba's family during the period in which they lived.

\subsection{The Family of Ibn Qāḍ Shuhba and Their Role in the Town of Shuhba and the Surrounding Areas}

The role of the family of Ibn Qàdī Shuhba was confined to the town of Shuhba and Hawrān during the Ayyubid era and the beginning of the Mamluk era. For instance, Jamāl al-Dīn was a judge in his hometown of Shuhba, and according to al-Jazarī, he was quite influential among his students and followers within

\footnotetext{
41 Ibn Qāạī Shuhba, Tārīkh ii, 130.

42 Ibn al-Jazarī, Tārīkh ii, 244.

43 Ibn Qāḍī Shuhba, I'lām (Yeni Cami manuscript) $101^{\mathrm{a}}$.

44 During the Mamluk and Ayyubid periods, every village or town used to have an imam to lead the prayers and to work as a judge as well. The person who used to occupy the two positions did not used to be a well-known scholar but rather someone who memorized the Quran and had a knowledge of figh rulings.

45 There is not much information about him in the sources, but we can roughly estimate that he probably was a judge during the reign of Baybars (r. 126o-77), and we can say with certainty that he was a judge during the reign of al-Manșūr Qalawūn until his death in 687. We can deduce this piece of information from Ibn al-Jazari's biography of Sharaf al-Dīn's son Najm al-Dīn 'Umar as he mentions that the latter remained a judge for 40 years, which means that he inherited his father's position around the year 687 (since Najm al-Dīn died in 727), and probably this is the year in which his father died.
} 


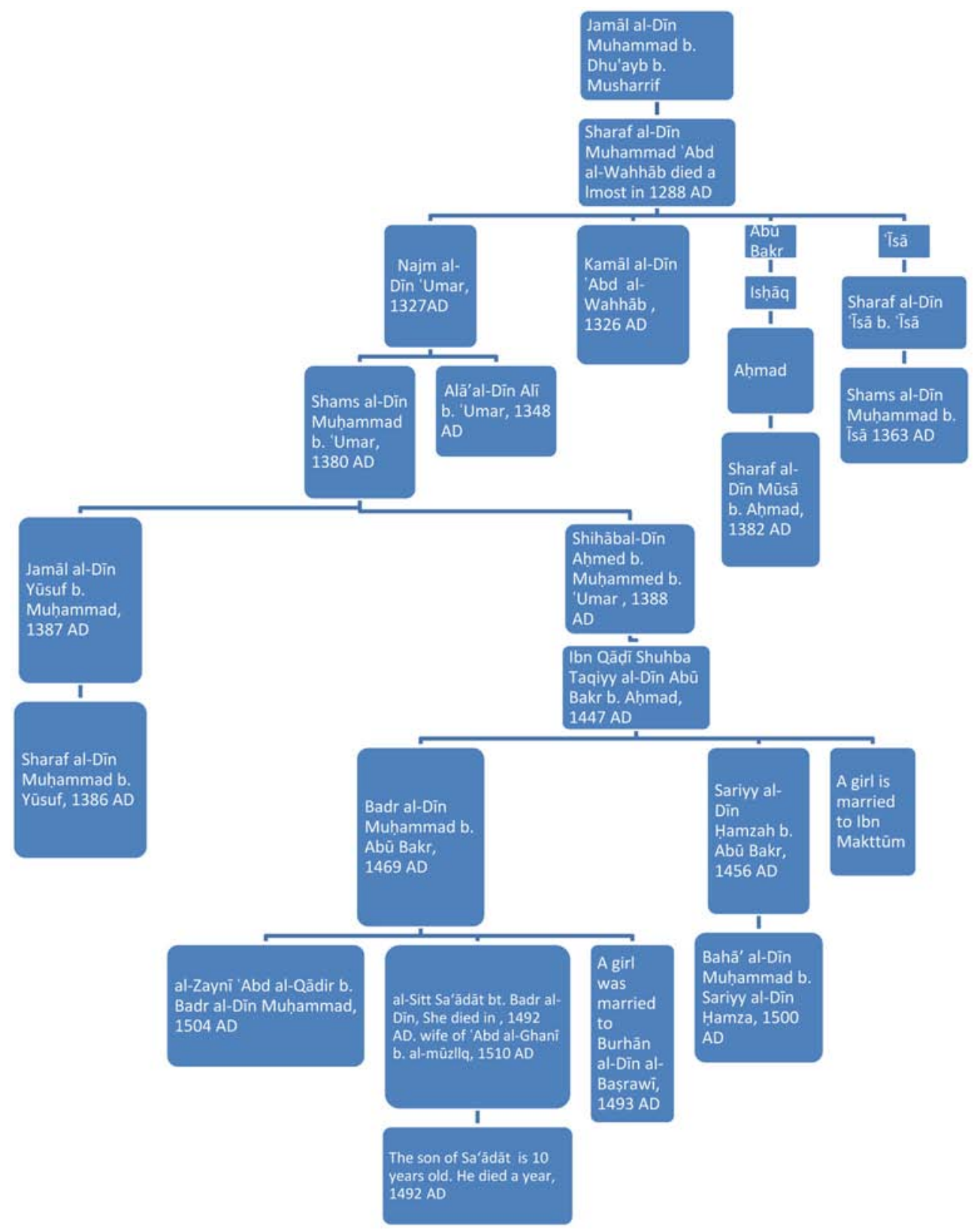

FIGURE 4.3 The extended family of Ibn Qāḍī Shuhba 
the area of Ḥawrān. ${ }^{46}$ As for his son, Sharaf al-Dīn Muhammad b. 'Abd alWahhāb, he inherited his father's position as a judge after his father's death, and he remained in this position until his death sometime around the year $687 / 1288$. It is not known exactly when his father Jamāl al-Din died, but it was most probably at the beginning of the Mamluk era. ${ }^{47}$

All branches of the family of Ibn Qâdī Shuhba actually descended from the abovementioned Sharaf al-Dīn Muhammad, judge of Shuhba in the Hawrān. He had four children, two of whom were to some extent well-known scholars, while the other two did not pursue scholarly careers (yet their descendants did).

Najm al-Dīn 'Umar is probably the eldest son of Sharaf al-Dīn. We can deduce this from the fact that he inherited the position of a judge after the death of his father since, as we already know, it was custom that the eldest son inherit his father's positions. Furthermore, he was named as one of his brother Kamāl al-Dīn's (born in 653/1255) ${ }^{48}$ teachers, which suggests that he was indeed the eldest, since it would not make sense that the younger brother taught the elder one.

Najm al-Dīn 'Umar had two sons who pursued scholarly careers. The first one was 'Alā' al-Dīn 'Alī who became the judge of Shuhba in 727/1327 after the death of his father and remained in this position for 22 years until his death by the plague in 749/1348. The second one was Shams al-Dīn Muhammad (born in 694/1295). Shams al-Dīn was the grandfather of Taqī al-Dīn b. Qāḍī Shuhba. He was sent to Damascus by his father who encouraged him to pursue a scholarly career in Damascus, which provided many more opportunities for a young scholar than the small town of Shuhba. ${ }^{49}$

Shams al-Dīn had two sons, who also pursued scholarly careers, and a daughter who married 'Alā' al-Dīn b. Hijjjī. Their son, Shihāb al-Dīn b. Hijjīi, also became a famous historian. ${ }^{50}$ The first one was Jamāl al-Dīn Yūsuf $b$.

46 Ibn al-Jazarī, Tārīkh ii, 244. The source of al-Jazarī's detailed information about the family of Ibn Qāọī Shuhba in his work Tārīkh hawādith al-zamān is Jamal al-Dīn's close friend Kamāl al-Dīn 'Abd al-Wahhāb, as they allegedly used to have long discussions about personal and scholarly issues (Ibn al-Jazarī, Tārīkh ii, 172). Interestingly, Taqī al-Dīn b. Qāḍī Shuhba had no knowledge of the information al-Jazarī mentioned except the part about his grandfather's travel to Baghdad, as he states in his book al-II ām bi-Tärïkh al-Islām (Ibn Qāḍī Shuhba, al-I'lām bi-tārīkh al-islām f. $101^{\mathrm{a}}$ ).

47 See note 44 .

48 Ibn al-Jazarī, Tārīkh ii, 172.

49 Ibn Qāọī Shuhba, Tārīkh iii, 5 1.

50 Al-Ghazzī, Bahjat 71. For more information on Shihāb al-Dīn b. Ḥijjī, see Massoud, Ibn Hijjī. 
Muhạmmad $(720-89 / 1320-87) \cdot{ }^{51}$ Jamāl al-Dīn had one son, ${ }^{52}$ Sharaf al-Dīn Muhạmmad b. Yūsuf, ${ }^{53}$ who was a judge in al-Zabadānī and died in Damascus in 788/1386. As for Shams al-Dīn's second son, Shihāb al-Dīn Ahmad b. Muhammad, who died in Damascus in $737-90 / 1337-88,{ }^{54}$ only one of his sons, Taqī al-Dīn b. Qāḍī Shuhba, showed interest in pursuing a scholarly career. Taqī al-Dīn b. Qâdịi Shuhba had three sons who pursued scholarly careers and a daughter. The first son was Badr al-Dīn Muhammad b. Abī Bakr (d. 874/1469), ${ }^{55}$ who had two daughters and a son. The first daughter was Sacādāt bt. Badr al-Dīn (d. 897/1492), ${ }^{56}$ who was married to al-Khawāja 'Abd al-Ghanī b. alMuzalliq, ${ }^{57}$ and they had one son, who died shortly after the death of his mother at the age of ten. ${ }^{58}$ The second daughter (whose name is unknown) was married to Burhān al-Bușrawī̄, ${ }^{59}$ and the son was al-Zaynī 'Abd al-Qādir, who was killed in 909/1504. ${ }^{60}$ Sarī al-Dīn Ḥamza b. Abī Bakr (d. 861/1457), the second son of Taqī al-Dīn, ${ }^{61}$ had only one son, whose name was Bahä' al-Dīn b. Sarī al-Dīn (905/150o). ${ }^{62}$ The third son was Jamāl al-Dīn Yūsuf b. Abī Bakr whom we have no information about, but his name was mentioned in the work that his brother Badr al-Dinn wrote about the biography of their father. ${ }^{63}$

The second son of the judge of Shuhba, Sharaf al-Dīn Muhammad, was Kamāl al-Dīn 'Abd al-Wahhāb b. Muḥammad b. 'Abd al-Wahhāb. Born in Shuhba in 653/1255, he was a student of his brother in Shuhba before his migration to Damascus. He was the first person from the family to have the epithet of Ibn Qāḍi Shuhba. The migration of Kamāl al-Dīn 'Abd al-Wahhāb to Damascus actually marked the appearance of the family of Ibn Qādī Shuhba on the scholarly scene in al-Sham. Kamāl al-Dīn was sent to Damascus by

\footnotetext{
51 Ibn Qāḍī Shuhba, Tārīkh iii, 237.

52 Ibid. 208.

53 Ibid. 207.

54 Ibid. 252.

55 Al-Bașrawī, Tārīkh 44.

56 Ibn Ṭawq, Tacīq iii, 1128.

57 He is al-Khawāja Zayn al-Dīn 'Abd al-Ghanī b. al-Muzalliq (d. 916/1510), the administrator of the religious endowment of Ibn Shams al-Dīn b. al-Muzalliq. See Ibn al-Ḥimṣī, Hawādith 457 .

58 Ibn Ṭawq, Ta'lìq iii, 1131.

59 Burhān al-Dīn al-Bușrawī was killed in 899/1493. Ibn al-Hiimṣī, Hawādith 240.

6o Ibn Ṭūlūn, Mufākahat 221.

61 Ibn al-Himṣì, Hawādith 79.

62 Ibn Ṭūlūn, Mut'at, ii 761.

63 Badr al-Dīn b. Qāọī Shuhba, Tarjamat 475.
} 


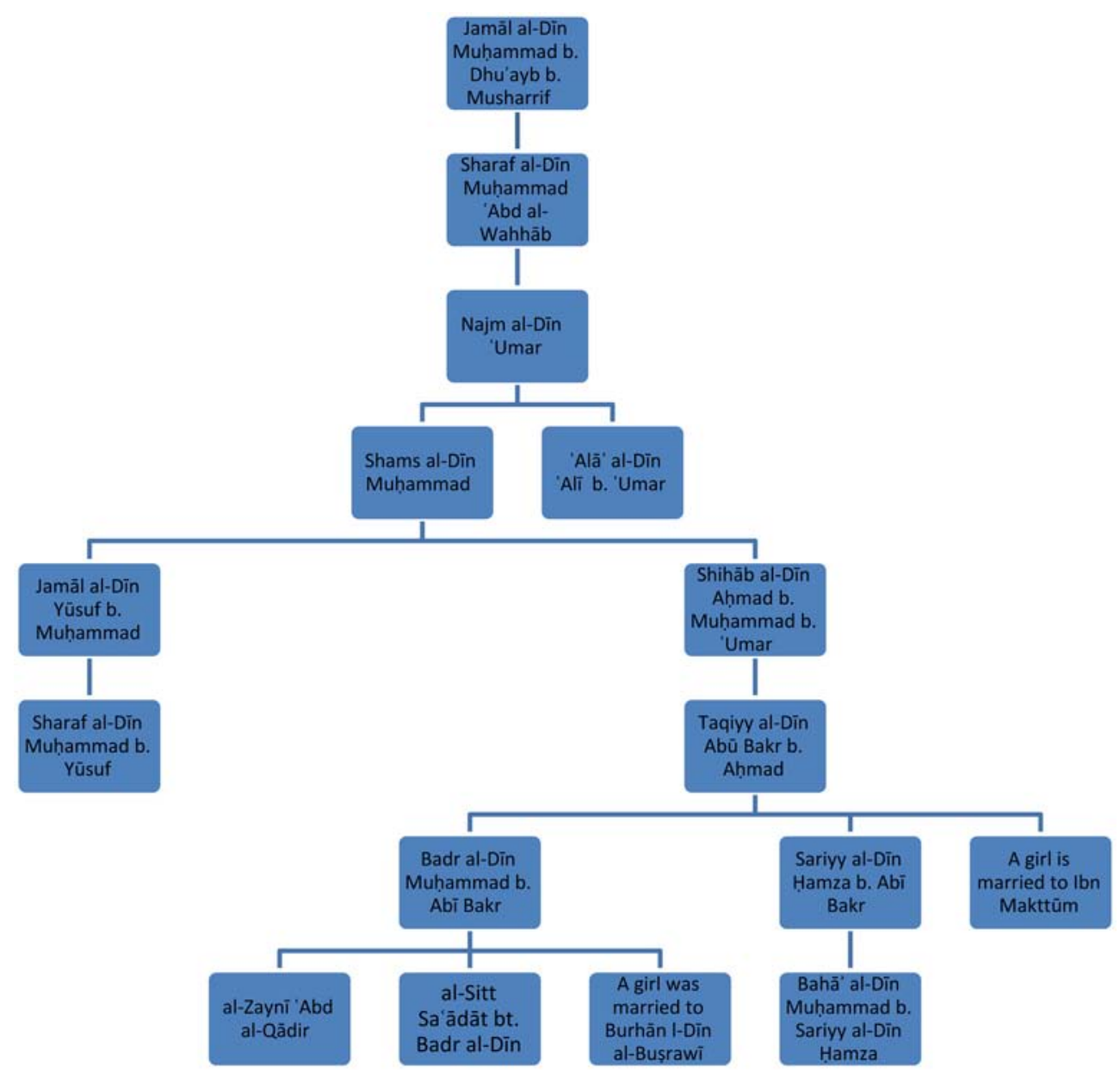

FIGURE 4.4 The first branch of Ibn Qāḍī Shuhba's family

his father Sharaf al-Dīn in order to pursue a scholarly career there. Most probably, this was because there were no available scholarly posts in the small town of Shuhba in this period since the judgeship position was reserved for his brother, Najm al-Dīn 'Umar. Therefore, Kamāl al-Dīn moved to Damascus and worked as a tutor for the sons of amirs and elites, while his brother inherited their father's position as a judge and started to prepare his eldest son 'Alā' al-Dīn 'Alī to inherit the post after him. However, as mentioned above, Najm al-Dīn 'Umar's other son, Shams al-Dīn (who is the grandfather of the protagonist of this paper, Taqī al-Dīn b. Qādị Shuhba) was sent to Damascus to follow in the footsteps of his uncle Kamāl al-Dīn, who had been sent to Damascus for the very same reason (i.e., the lack of available posts 
Jamāl al-Dīn

Muhammad b. Dhu'ayb

b. Musharrif

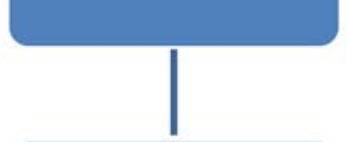

Sharaf al-Dīn

Muhammad 'Abd alWahhāb

Kamāl al-Dīn 'Abd alWahhāb b. Muhammad b. 'Abd al-Wahhāb
FIGURE 4.5

The second branch of Ibn Qāọī Shuhba's family

in Shuhba). Kamāl al-Dīn did not get married, and he had no children. He died in $726 / 1326 .^{64}$

The third son of Sharaf al-Dīn Muhammad was 'Īsā b. Sharaf al-Dīn Muhammad. We have very little information about him, probably because, as far as we know, he did not pursue a scholarly career. 'Tsă’s son, Sharaf al-Dīn 'Īsā, was a scholar whom we know very little about as well. However, the latter's son, Shams al-Dīn Muhammad, was the chief of the chancellery ( $k \bar{a} t i b$ al-insh $\left.\bar{a}^{\prime}\right)$ in Damascus and Gaza, ${ }^{65}$ and he had quite a good relationship with the famous scholar al-Ṣafadīi, as suggested by the many literary correspondences that the latter mentions in his work al-Tadhkira. ${ }^{66}$ Shams al-Dīn Muhammad died in Gaza in $764 / 1363 \cdot{ }^{67}$

The fourth son of Sharaf al-Dīn Muhammad was Abū Bakr b. Sharaf al-Dīn. We know almost nothing about him except that his grandson Sharaf al-Dīn Aḥmad b. Mūsā b. Isḥāq b. Abū Bakr (d. 785/1383) pursued a scholarly career. ${ }^{68}$

64 Ibn Kathīr, Bidāya xviii, 275.

65 Ibn Ḥabīb, Durrat, f. 204 'ं Ibn Qāḍī Shuhba, Tārīkh ii, 197.

66 Al-Ṣafadī, $A^{\prime} y \bar{a} n$ v, 42.

67 Ibn Qādị Shuhba mistakenly mentions him in the obituaries of the year 762 .

68 Ibn Qàḍī Shuhba, Tärīkh iii, 102. 


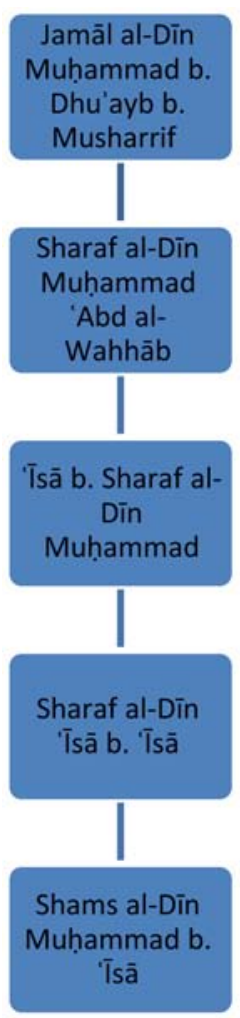

FIGURE 4.6

The third branch of Ibn Qāḍī Shuhba's family

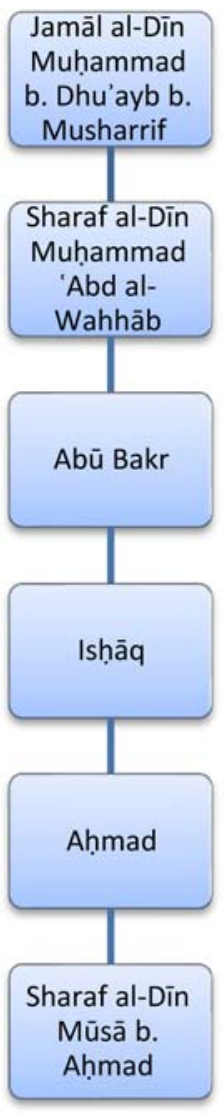

FIGURE 4.7

The fourth branch of Ibn Qāḍī Shuhba's family

After the discussion of the origins and whereabouts of Ibn Qāḍi Shuhba's family in the previous parts of this paper, I will now discuss in the next parts the life and works of Taqī al-Dīn b. Qāḍī Shuhba. I will focus in particular on examining his historiographical works, but I will not discuss his Fiqhī works.

\subsection{His Early Life}

His full name is Abū l-Ṣidq Taqī al-Dīn Abū Bakr b. Aḥmad b. Muḥammad b. 'Umar b. Muḥammad b. 'Abd al-Wahhāb b. Muhammad b. Dhu’ayb b. Mushar- 
raf b. Qāḍī Shuhba al-Shāfi'i al-Asharaì. He was born in Damascus in 779/1377. He learned the Quran and summaries of figh and principles of religious works while he was eight years old. His father also gave him special attention, as he seems to have hoped that his son would inherit his religious positions. Tellingly, Taqi al-Dīn's father reportedly already made him the imam of the prayers during the holy month of Ramadan when he was only nine years old, and he continued this for three years until his father's death. ${ }^{69}$

\subsection{His Education and Main Teachers}

Ibn Qāḍī Shuhba studied under many scholars of his time, especially jurists, as he was interested mainly in studying Shāfici jurisprudence. Therefore, he was more famous for being a jurist than a historian. Almost all the historians who discuss the biography of Ibn Qādī Shuhba in their works described him as a jurist and not a historian. The only exception is al-Suyūțī, who describes him in his work as "naẓm al-'uqyān" or "the historian of al-Sham." ${ }^{\prime 0}$ Some of Taqī al-Dīn's teachers influenced his personality and life substantially. Among other teachers he benefited from, his most important influencers were Sharaf al-Dīn al-Ghazzī, ${ }^{71}$ Sirāj al-Dīn al-Bulqīnī, who taught him jurisprudence and influenced his style, his father-in-law, ${ }^{72} \mathrm{Badr}$ al-Dīn Muhammad b. Maktūm, ${ }^{73}$ who taught him jurisprudence and Arabic, and his cousin the historian, Shihāb alDīn b. Hijjī , who taught him history and was one of the reasons why Taqie al-Dīn became a historian.

\subsection{His Career}

Ibn Qāḍi Shuhba assumed no less than 13 posts during his reign. His jobs were not limited to one particular specialty, as he worked as a judge, teacher, and orator. He occupied some of these posts until his death, such as teaching in schools and mosques, while he was deposed from other posts, such as the judiciary and oratorship. In this part, I will discuss briefly each of the different posts he occupied.

Ibn Qāọī Shuhba started his career at the young age of twelve after he inherited his father's posts and while he remained under the guardianship of his

\footnotetext{
69 Badr al-Dīn b. Qāộ̄ Shuhba, Tarjamat 476.

$70 \quad$ Al-Suyūṭī, Nazm 49.

71 He is the jurisprudence scholar Sharaf al-Dīn đĪsā b. 'Uthmān b. Īsā al-Ghazzī (d. 799/1397). Al-Zarkalī, A'lām v, 105.

72 See Badr al-Dīn b. Qāạī Shuhba, Tarjamat 464. He is the judge of Greater Syria, Sirāj al-Dīn 'Umar b. Raslān al-Bulqīnī (d. 8o5/1403). Al-Zarkalī, A'ām v, 46.

73 Badr al-Dīn Muḥammad b. Aḥmad b. Maktūm al-Suwaydī (d. 797/1395). Ibn Ḥajar, Inb $\bar{a}^{3}$ i, 502 .
} 
father's friend, Sarī al-Dīn al-Maslātī. ${ }^{74}$ Ibn Qāḍī Shuhba assumed his father's jobs after he reached puberty, sometime between 793/1391 and 798/1396, in a ceremony that was attended by his guardian Sarī al-Dīn al-Maslātī and many scholars and judges. ${ }^{75}$ However, he only assumed his first real job, other than the ones he inherited from his father, after 8oo/1398, when he became a teacher in the Umayyad Mosque in Damascus. Hereafter, he occupied many other jobs.

Regarding his work in the judiciary, he at first worked as an assistant judge (ca. 820/1417) $\cdot{ }^{76}$ Then, he officially became a judge in $842 / 1438$ when Burhān alDīn al-Bā'ūnī ${ }^{77}$ resigned from this position. ${ }^{78}$ Regarding his career as a teacher in the mosques and schools, Ibn Qādī Shuhba taught in several schools and mosques in Damascus. However, it appears that he did not officially teach in most of them. Rather, he is reported to have had to pay huge sums of money to the teachers so they would give their positions to him. According to his biographer, this is why he went through financial difficulties, as he had a lot of debts. ${ }^{79}$ Ibn Qāḍi Shuhba made sure his sons would occupy some of his positions, so he gave some of them to his sons Badr al-Dīn Muhammad, Sarī al-Dīn Ḥamza, and Jamāl al-Dīn Yūsuf. ${ }^{80}$

\subsection{Ibn Qãdì Shuhba and the Science of History}

There are several factors that helped draw Ibn Qāḍi Shuhba's attention to historiography, the most important of which were social ones, such as his kinship relation with the famous Damascene historian Ibn 'Asākir. His grandmother was allegedly related to Ibn 'Asākir's brother through marriage and was hence his descendant. ${ }^{81}$ This relationship probably motivated him to study history. For instance, many other Muslim scholars throughout Islamic history tried to link their genealogy to the Prophet Muhammad, one of his companions, or one of the prominent scholars, since this was a matter of pride, as many biographical works clearly show. Anyway, the following chart shows the kinship relationship between Ibn Qāḍī Shuhba and the Damascene historian Ibn 'Asākir.

\footnotetext{
74 He is the judge Sarī al-Dīn Muhammad b. Muḥammad al-Maslātī (d. 799/1397). Ibn Taghrībirdī, Nujūm xii, 16o.

75 Badr al-Dīn b. Qāḍī Shuhba, Tarjamat 486.

76 Badr al-Dīn b. Qāọī Shuhba, Tarjamat 489.

77 He is the judge Burhān al-Dīn Ibrāhīm b. Ahmmad b. Nāṣir al-Bācūnī (d. 870/1465). Al-Zarkālī, Alām i, 30.

$78 \quad$ Al-Maqrī̄ī, Sulūk vii, 391.

79 Badr al-Dīn b. Qāḍī Shuhba, Tarjamat 473.

8 o Ibid. 475 .

81 Ibn Ṭūūn, Thaghr 168.
} 


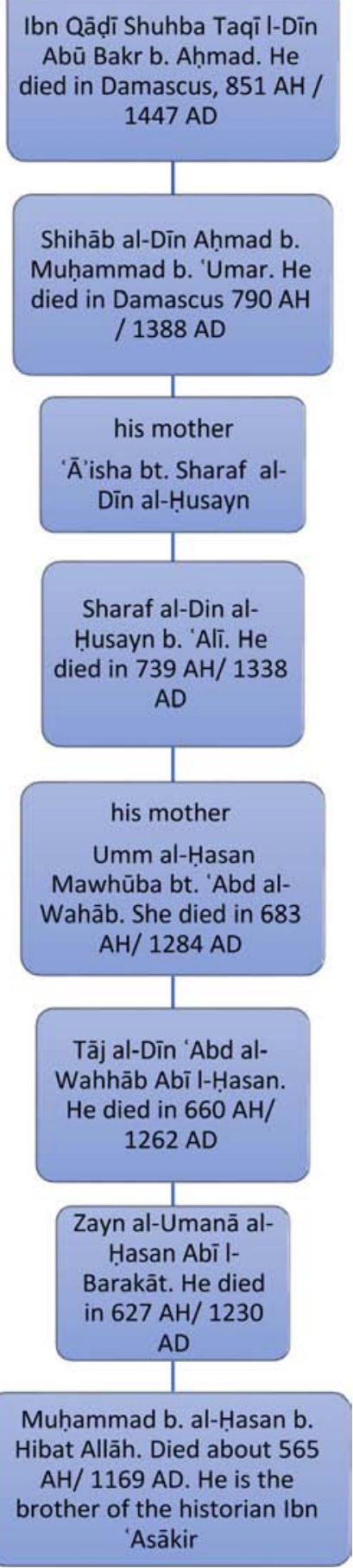

FIGURE 4.8

The lineage of the mother of Ibn Qāḍi Shuhba 
Furthermore, there was his growing up in a house that probably contained a lot of historiographical books since his grandfather, Shams al-Dīn b. Qāḍi Shuhba, was interested in studying history and owned many history and sira works. Ibn al-Āqūlī, who was one of the students of Shams al-Dīn, mentioned that the latter was interested in history and had good knowledge of it. ${ }^{82}$ Naturally, people would obtain historical knowledge through reading, and this would suggest, from my point of view, that Shams al-Dīn, like most other scholars, had quite a large collection of historiographical works in his library. Most probably, Ibn Qāḍi Shuhba inherited this collection through his father, as both were the only heirs, and he then read historiographical and biographical dictionaries, which motivated him to study history.

Finally, there also was the fact that Ibn Qàdī Shuhba was a disciple of his cousin, the historian Shihāb al-Dīn b. Hijjī, who seems to have been the main reason behind Ibn Qāọī Shuhba's decision to become a historian. Ibn Hijjī himself studied under many influential historians, like Ibn Kathīrrs and Ibn Rāfic al-Sallāmī, ${ }^{84}$ who in turn had studied under other influential historians, such as al-Dhahab $\overline{1}^{85}$ and al-Birzālī. ${ }^{86}$ This influenced his style of historiographical writing, since it combined the styles of the aforementioned historians. Ibn Kathīr, for instance, was mainly interested in recording political and social events, while he was less interested in biographies, as he borrowed the style and approach of his teacher al-Birzāli (except when it came to the scholars' biographies as al-Birzālī, unlike Ibn Kathīr, was interested in them as well). Ibn Rāfi al-Sallāmī, ${ }^{87}$ on the other hand, was more interested in the biographies of scholars and some amirs and was less interested in recording political and social events. In this regard, Ibn Rāfic followed in the footsteps of his teacher al-Dhahabī, who was broadly interested in the biographies of Muslim scholars, focusing especially on the biographies of hadith scholars, as we can infer from his two works Kitāb Tārīkh al-Islām and Siyar a'ām al-nubalā. Moreover, one of al-Dhahabìs notebooks shows his interest in mainly hadith scholars.

\footnotetext{
$82 \quad$ Ibn al-'̄̄qūīi, Dirāya 378.

83 He is the historian 'Imād al-Dīn Ismāōil b. 'Umar b. Kathīr (d. 774/1373). Al-Zarkālī, A'lām i, 320.

84 Ibn Qāḍī Shuhba, Ṭabaqāat iv, 13.

85 He is the historian Shams al-Dīn Muhammad b. Aḥmad al-Dhahabī (d. 748/1339). AlZarkalī, A'tām v, 326 .

86 He is the historian 'Alam al-Dīn al-Qāsim b. Muhammad al-Barzālī (d. 739/1339). AlZarkalī, A'lām v, 182.

87 He is the historian Taqī al-Dīn Muhamamad b. Rāfi` b. Hajras al-Sallāmī (d. 774/1372). AlZarkalī, A'tàm vi, 124.
} 


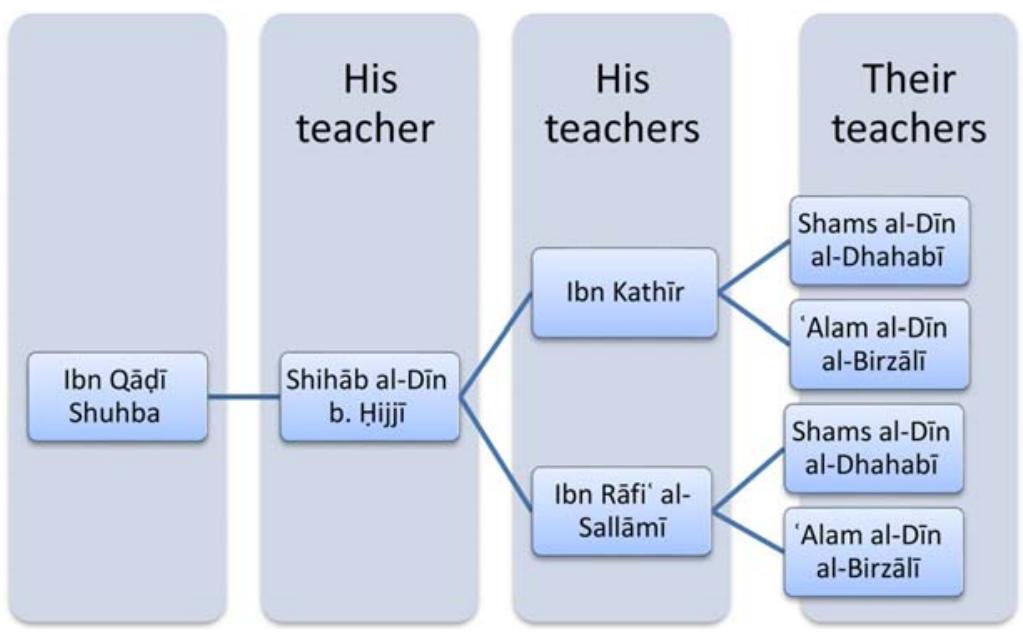

FIGURE 4.9 The chain of Ibn Qāḍī Shuhba's teachers of history

In his summary of Ibn al-Dubaythī's history work, Dhayl tārïkh Baghdād, ${ }^{88}$ alDhahabì chose to include the biographies of hadīth scholars, or people who had a broad interest in hadith, instead of including significant poets, doctors, or authors. ${ }^{89} \mathrm{Ibn}$ Qāḍī Shuhba, however, combined both approaches as he started by mentioning the political and social events in a certain year, then proceeded with mentioning the biographies of the people who died during that year.

I will further expatiate on Ibn Qāḍi Shuhba's methodology when I discuss his historiographical works below.

\subsection{His Death}

Ibn Qādị Shuhba died in Damascus in the year 851/1448 in his house in the neighborhood of al-'Uqayba, outside the walls of Damascus, near the mosque of al-Tawba (in which he used to teach after al-Fajr prayer till al-Zuhr prayer). He apparently died quite suddenly, yet he had a major funeral. Also, when the news that he had died reached his friend Ibn Hajar, the latter is reported to have prayed Șalāt al-Ghäib (a prayer for the person who dies in a faraway land). Ibn Qāḍi Shuhba was buried in his family's grave at the Bāb Șaghīr cemetery, as established by Kamāl al-Dīn b. Qadi Shuhba, the first person from the family who migrated to Damascus. The burial was allegedly located near the graves of the martyrs of Karbala and the sons of al-Ḥusayn and 'Alī b. Abī Tâlib.

88 Al-Dhahabī, Mukhtașar i, 223.

89 Ibn al-Dubaythī, Muqaddimat i, 127. 


\subsection{His Works and Drafts}

Ibn Qadi Shuhba was a prolific author despite the many positions he held. This was most probably a result of his excellent time management, as, according to his biography, he used to teach during the time between al-Fajr and al-Zuhr prayers, and from al-Zuhr till al- Ishä prayers, he used to write and prepare for his coming classes. ${ }^{90}$

All the works and drafts ${ }^{91}$ Ibn Qadi Shuhba wrote were either juristic or historiographical. It is noteworthy that most of these works were historiographical ones, and that he, nonetheless, was mostly known as a jurist, as I discussed above. In this paper, I will discuss his historiographical works and drafts, which will be divided into two categories: the works he wrote for the public and the works he wrote for his personal use.

\subsubsection{His Nonhistoriographical Works}

The following is a brief list of his nonhistoriographical works and drafts, which are mainly fiqhī ones:

1. Kifāyat al-muhtāj ilā sharh al-minhāj (al-Sharḥ al-kabïr):92 This work is a commentary on the work of Minhäj al-țalibin of al-Nawawi. However, he did not finish it, as he stopped at the Bāb al-Khul'. 93

2. Iqnā'al-muhtāj ilā sharh al-minhāj (al-Sharh al-Ṣaghïr): Another work he did not finish, as he stopped at the Bāb al-Sullam. ${ }^{94}$

3. Nukat kubrā 'alä al-tanbīh (al-Sharh al-kabìr): This work is a commentary on the work al-Tanbīh fí l-figh of Abū Ishāq al-Shīrāzì. He commented on the part from Bāb al-Siyām to Bāb al-Nikāh (but he did not finish it). ${ }^{95}$

4. Käfíal-nabìh fìnukat al-tanbīh (al-Sharh al-Saghīr). ${ }^{96}$

5. Fatawā Ibn Qādī Shuhba: ${ }^{97}$ This work is a collection of his legal rulings. However, we are not sure if he compiled the work himself or if one of his students carried out this task.

9o Badr al-Dīn b. Qāọī Shuhba, Tarjamat 480.

91 By drafts I mean the notes he wrote for his personal use.

92 This work is still a manuscript in Maktabat al-Asad in Damascus. It is written in two volumes, which have the shelf marks 9185 and 17635 .

93 Badr al-Dīn b. Qādịi Shuhba, Tarjamat 477.

94 Ibid.

95 Ibid.

96 This work is still a manuscript in Maktabat al-Asad in Damascus. Its title is Käfı́al-nabīh fi tahrìr al-tanbīh, which has the shelf mark 16878 .

97 This work is still a manuscript in Maktabat the Mufti of Damascus, Abū l-Yusr 'Ābdīn, under the shelf mark 33 . 
6. Nukat 'aläl-muhimmāt: ${ }^{98}$ Most probably, this work was compiled/written by one of his students as his son presages in his writing about his father.

7. Tafsir al-qur'ān:99 This is an unknown work, which has not been mentioned by either the contemporaries of Ibn Qādī Shuhba or the people who are familiar with his works. It was only mentioned by Hạjjì Khalīfa in his early modern bio-bibliographical work Kashfal-zunūn. Probably, Ḥājjī Khalīfa was mistaken since even Badr al-Dīn, the son of Ibn Qādīi Shuhba, did not mention any tafsir work in his list of his father's works. So, perhaps Ḥājjī Khalīfa had seen a tafsìr text in the hand of Ibn Qāḍi Shuhba and mistakenly thought that Ibn Qāḍi Shuhba was the author, given that the latter used to copy many other scholars' works. ${ }^{100}$ What we are sure about is that Ḥâjjī Khalīfa was familiar with Ibn Qādị Shuhba's handwriting, as the former had consulted the latter's works in his two works Kashf al-zunū $n^{101}$ and Sullam al-wușül. ${ }^{102}$

8. Sanad fi l-hadith:103 This small treatise consists of ten folios in which he mentions the hadith works he heard and for which he obtained ijäzät (permissions).

\subsubsection{His Historiographical Works}

As suggested, this section will be divided into two categories: the works he wrote for the public and the works he wrote for his personal use.

\subsubsection{The Works He Wrote for the Public}

Ibn Qādī Shuhba wrote several historiographical works. The perspectives, forms, and authorship of these books varied. Some of them dealt with universal history, like his book al-I' lām bi-tārikh ahl al-islām, in which he wrote about the history of Islam in general. Some other works were more specialized, like Tabaqāt al-Shäficiyya, in which he focused on the prosopography of Shāfīi scholars. Also, some of these works have remained just drafts, while others have been edited and formally published. Regarding the authorship, some of these works were written by Ibn Qāḍī Shuhba alone while he coauthored others:

\footnotetext{
$98 \quad$ Ḥājjī Khalīfa, Kashf i, 438.

99 Ḥājjī Khalīfa, Kashf ii, 1914.

1 oo Badr al-Dīn b. Qāḍī Shuhba, Tarjamat 476.

101 Ḥājjī Khalīfa copied many works of Ibn Qāẹī Shuhba.

102 Ḥājjī Khalīfa, Sullam i, 62.

103 This treatise is still a manuscript and exists in the library of Princeton University under shelf mark $795 \mathrm{H}$.
} 


\subsection{Takmïl tārīkh ibn Hijji}

This is Ibn Qāḍi Shuhba's first historiographical work, and his starting point for many others to come. Furthermore, he trained and practiced writing history while conducting this work, which he wrote after his teacher Ibn Hijjijust before his death-asked him to complete his unfinished work. Ibn Hijji wrote a historiographical work that deals with the history of the years between 741/1340 and 815/1412. However, he died before completing his work, as he did not write anything about the events that occurred between the years 748/1347 and 768/1367. ${ }^{104}$ Therefore, Ibn Qāḍi Shuhba coauthored this work and completed it following the same style and approach of Ibn Hijjīi in doing so. ${ }^{105} \mathrm{Ibn}$ Hiijjī surely would not have asked Ibn Qāḍi Shuhba to complete his work if he did not believe the latter was qualified enough to carry out this task, since Ibn Qãdī Shuhba showed great interest in history during the many years in which he was a student of Ibn Hijjji.

\subsection{Dhayl 'alā tārīkh ibn Kathīr ${ }^{106}$}

This seven-volume work was originally based on Ibn Hijjì's history, which they coauthored. ${ }^{107}$ However, Ibn Qâại Shuhba added to his teacher's work many

104 The reason behind Ibn Hijjis's decision to not record the events of that year is that he wanted to write a dhayl for Ibn Kathīr's work. However, there are two versions of Ibn Kathīr's history. The first version, which was widely circulated during the time of Ibn Hijji, ends after dealing with events of the year 740, while the second version, where each year was listed separately, ends with the events of the year 768 . I would suggest that Ibn Hijjī probably started writing a dhayl for the first version of Ibn Kathïr's work, then he discovered the second version of the work after writing about the events of the year 748. Therefore, he continued writing starting from 769 and did not deal with the period between 748 and 768 . I came to this conclusion because I do not believe that it was a coincidence that Ibn Kathī's second version of his history work ends with the year 768 and Ibn Hijji's work starts with the year 769 . The similarities in style and organization between the two works (except that Ibn Kathīr tended to neglect many biographies) further suggests that Ibn Hijjī aimed to write a dhayl of Ibn Kathïr's work.

105 Ibn Qāḍī Shuhba, Ṭabaqāt iv, 13.

106 This work was mentioned by Badr al-Dīn b. Qādīi Shuhba. Three manuscripts of this work were found, all written by Ibn Qādīi Shuhba: 1. The first one is located in Chester Beatty Library in Dublin under shelf mark 5527. This volume covers 14 years (the period between 797 and 810), and David C. Reisman wrote an article about it in the MSR (1998). 2. The second volume is located in Gotha Library under shelf mark 1574 and covers eleven years (between 824 and 834). (I am currently working on the edition of this manuscript.) 3. The third manuscript (which I have edited as well) is located in the collection of the India Office Library (Arab manuscripts) under shelf mark 3805 . This volume covers three separate years $(841,842$, and 846$)$.

Ibn Qāḍī Shuhba, Ṭabaqāt iv, 13 . 
events that occurred in al-Shām and elsewhere as well as biographies, which he collected from the works of, among many other historians, al-'Irāqī, al-Ṣafadī, Ibn Ḥabīb, Ibn Shākir al-Kutubī, Ibn Kathīr, Ibn al-Furāt, and Ibn Duqmāq. This Dhayl covers the period from 741/1340 to 840/1437. However, Ibn Qādī Shuhba kept recording the events that occurred after the year $840 / 1437$, as I have found an autograph manuscript of his in which he records the events of several scattered years (i.e., 841,842 , and 846 ). ${ }^{108}$ I have also noticed that some later historians quoted events from Ibn Qāḍi Shuhba's history that occurred in the year 851. ${ }^{109}$ Therefore, it has become clear to me that Ibn Qãḍi Shuhba continued writing his historiographical work until just before his death because it covered a period of around no hijri years.

When it comes to the methodology and organization of this work, Ibn Qāḍi Shuhba, as he mentions in his introduction to the work, followed the same methodology of his shaykh Ibn Hijjjī in his work..10 Furthermore, Ibn Qādī Shuhba, probably under the influence of earlier historians, such as Ibn Aybak al-Dimyāțị111 and Ibn al-Misallātīi, ${ }^{112}$ gave special attention to the history of scholarly families. ${ }^{113}$ For instance, whenever he wrote a biography of a person from a scholarly family, he continued to mention other members of his/her family who also pursued a scholarly career.

\subsection{Mukhtașar dhayl tārīkh Ibn Kathīr}

This book is an abridgment of his book Dhayl 'alā tārīkh Ibn kathïr, which, as just mentioned, was in turn built on the historiographical work of his teacher Ibn Hijji. The size of this abridgment is almost one-third of the original work. ${ }^{114}$ As for the methodology and organization of this abridgment, Ibn Qādī Shuhba followed a different organization method than the original work. He followed the organization method of his shaykh Ibn Hijji in the original, whereas, in the abridgment, he decided to follow al-Dhahabī's organization of his Tārikh alIslām, especially when it came to the biographical entries, which al-Dhahabì arranged alphabetically for each year in order to facilitate the search for a spe-

108 This manuscript, which I have recently edited, is in the holdings of the India Office Library (Arab manuscripts) under the shelf mark 3805 .

109 See, for example, al-Nu'aymī, Dāris ii, 20; Ibn Ṭūlun, Thaghr 258.

110 Ibn Qādīi Shuhba, Ṭārīkh i, 111.

111 He is Shihāb al-Dīn Aḥmad b. Aybak al-Dimyāțī (d. 749/1348). See al-Zarkalī, A'ām i, 102.

112 He is Jamāl al-Dīn Muhammad b. 'Abd al-Raḥīm al-Misallātì (d. 771/1370). See Ibn Ḥajar, Durar.

113 See, for example, Ibn Aybak, Tarājim i, 243; Ibn al-Misallātì's manuscript of Wafayāt f. 246.

114 Ibn Qāḍī Shuhba, Ṭārīkh i, 111. 
cific person in it. ${ }^{115}$ Ibn Qāḍī Shuhba also followed al-Dhahabī's organization in the way he detailed the works of each author he included in his biographical entries. This specific organization, in addition to Ibn Qādīi Shuhba's explicit documentation of the sources for each piece of information he included in this work, was the reason behind Ḥājjī Khālīfa's dependency on this work. ${ }^{116}$

Ibn Qāḍi Shuhba only dealt with selected years from the original history, which are the 67 years from $741 / 1340$ to $808 / 1406$. Most of the information in this book was taken from the works of earlier historians, like al-Ṣafadī, Ibn Ḥabīb, al-'Irāqī, Ibn Shākir al-Kutubī, al-Ḥusaynī, and Ibn Sanad. Anyhow, I cannot discuss here the full list of sources used in this work as this would probably require an entire article in itself.

\subsubsection{4 al-Ilām bi-tārīkh al-Islām al-muntaqā min tārīkh al-Islām li-l-dhahabì wa-mā udịfa ilayhi min tārīkh ibn Kathīr wa-l-Kutubī wa ghayrihim ${ }^{117}$}

This book is the biggest and most comprehensive work of Ibn Qādī Shuhba. As we can infer from the title, the historical materials in this work were collected from earlier sources such as, among many others, Tärïkh al-Islām of al-Dhahabī, al-Bidāya wa-l-nihāya of Ibn Kathīr, and 'Uyūn al-tawārīkh of Ibn Shākir al-Kutubī. Al-I'āam bi-tärīkh al-islām covers the period between 200 and 799. ${ }^{118}$

I must note that Ibn Qādī Shuhba's choice of the first year that this work covers (i.e., 20o) is quite odd and unprecedented, since most of the historians who dealt with early Islamic history either started their works by dealing with the creation of the world up to their own eras (e.g., al-Balkhī in Kitāb alBad' wa-l-ta'rīkh, al-Ṭabarī in Tārīkh al-rusul wa-l-mulük, and Ibn al-Jawzī in al-Muntazam fi tärīkh al-mulūk wa-l-umam) or with the beginning of Islam up to their own eras (e.g., al-Dhahabī in Tärīkh al-Islām and Ibn Shākir alKutubī in 'Uyūn al-tawārīkh). It is quite peculiar as well that the starting point of the three works that were Ibn Qāḍi Shuhba's main sources in writing his

\footnotetext{
115 Ibid.

116 See, for example, Ibid., 196-9, 213, etc.

117 This work has several surviving manuscripts all of which are autographs of the author. These manuscripts exist in different libraries: 1. Two volumes are held in Morocco in alKhizāna al-Āmma bi-l-Rabāt under classmark (94), in which the first volume covers 109 years (from $45^{-}-560$ ) and the second volume covers 69 years $(561-630)$. 2. One volume is held in Sulaymanye library in Istanbul under classmark (1403), which covers 70 years (6oo-67o). 3. One volume from the collection of Yeni Cami also in the Sulaymanye library under classmark (864) covers the period from 701-40 (though the last 20 folios of this volume are not written by Ibn Qāẹī Shuhba).

118 Badr al-Dīn b. Qāọī Shuhba, Tarjamat 479.
} 
work was the beginning of Islam, while al-Iläm bi-tārīkh al-Islām started by dealing with the year 200. One might speculate that Ibn Qādī Shuhba tried to avoid dealing with the problematic period of early Islam (mainly starting from 'Uthmān b. 'Affān's reign until the early Abbasid era), especially when his tribe had a prominent role in the political turmoil in this era. As I have mentioned above, the branch of Banū Ghāḍira, from which Ibn Qāḍi Shuhba is descended, is remembered to have supported 'Alī b. Abī Ṭālib against his opponents and his son Husayn in his battle against Yazīd b. Mu'awiy and adopted Shicism after the formation/crystallization of the Islamic sects. Had Ibn Qāḍi Shuhba dealt with the first 150 years of Islamic history in this book, he would have been obliged to mention that the members of his tribe supported 'Alī b. Abī Țâlib and later on became Twelver Shicites. Furthermore, Ibn Qāḍī Shuhba concealed that he was from Shi ite origins, as he mentions that he descended from Banū Asad without specifying whether he was from the Shicite or Sunni branches. This is also quite clear in his discussion of the biography of his relative Muḥammad b. 'Īsā b. Qāḍī Shuhba, as he was keen to hide that he was from Banū Ghādira, despite this piece of information being mentioned by al-Ṣafadī, who was Ibn Qāộ̄ Shuhba's source for Muḥammad b. 'Īsā’s biography.119

As for the organization of this book, Ibn Qāḍi Shuhba again followed alDhahabī's organization of Tārikkh al-islām, as he mentions the historical events in a specific year followed by the obituaries.

However, unlike al-Dhahabī, he did not organize these obituaries alphabetically.

3.6.2.1.5 Tabaqātal-Shäficiyya

This book was extensively copied during the author's lifetime, and we found his handwriting on most of its surviving manuscripts. Anyhow, I will not discuss this book in detail here since 'Abd al-'Alīm Khān made a very good study of it in his introduction to his edition of the work. ${ }^{120}$

119 Al-Ṣafadī, Áyān v, 42. Al-Ṣafadī actually claims to have been a close friend of Muhammad b. '⿳亠̄sā.

120 The manuscript of this work is held in al-Maktaba al-Zāhiriyya under classmark (438). There is manuscript in Chester Beatty library that has the title Tabaqāt al-nuhāh li-ibn Qãḍ̄ Shuhba. However, after examining the manuscript, it turns out that it is rather a manuscript of al-Fīrūzābādī's work al-Bulgha fì tarājim a’immat al-naḥw wa-l-lugha. 
3.6.2.1.6 al-Tabyìn fì țabaqāt al-nuhāh wa-l-lughawiyyīn ${ }^{121}$

This book was written twice. At first, Ibn Qāḍi Shuhba arranged it by annals. Then, he rearranged it alphabetically to ease the access to the biographies of specific persons. This book was written after Tabaqāt al-Shāficiyya since we find many references in al-Tabyīn to the Tabaqāt al-Shäfi iyya. ${ }^{122}$

\subsection{Manāqib al-Imām al-Shāfīìwa-țabaqāt aṣhābihi min tārīkh al-Islām}

It is a selection of the biographies of Shāfi'ī scholars in al-Dhahabī's work Tārīkh al-Islām.

\subsection{Lubābal-tahdhīb}

In this work, Ibn Qāọī Shuhba summarizes and combines two different works: Tahdhīb al-kamāl of al-Mizzī and Tadhhīb tahdhīb al-kamāl of al-Dhahabī.

\subsection{Tärīkh binä madinat Dimashq}

This is a summary of the first volume of Ibn 'Asākir's work Tārīkh Dimashq, which deals with the urban history of the city of Damascus. ${ }^{123}$

\subsubsection{Ibn Qạ̣̄̄ Shuhba’s Selections (Muntaqayāt)}

The literary genre of "selections” constitutes the majority of Ibn Qāọi Shuhba's works. Nonetheless, most of the studies of Ibn Qādī Shuhba's life or works rarely discuss these works. I will start here by briefly discussing historians' perceptions of the difference between the genres of selections (muntaqayāt) and summaries/abridgments (mukhtșarāt). When historians speak of an abridgment, it means that this work maintained the original work's structure, but it was shortened. In other words, if the original contained 200 biographical entries, the abridgment should also contain 200 entries but each entry would have less information. For instance, Ibn Hajar's abridgment of al-Ṣafadì's alWāfi bi-l-wafayāt contains 14,195 biographical entries, which is exactly as many as the original work. ${ }^{124}$ Selections are quite different from abridgments in the sense that a work of the former genre consists of the information the author deems important for his personal use without being restricted by the original work's number of entries, chapters, etc. Many historians wrote selective works to use as a reference while writing their original work, like al-Dhahabī and

\footnotetext{
121 Badr al-Dīn b. Qāọī Shuhba, Tarjamat 479.

122 Ibn Qāḍī Shuhba, Ṭabaqāt al-nuhạh 61.

123 Ibn Qādīi Shuhba, Tārīkh (manuscript) $2^{\text {a }}$.

124 Faydullah Effendi Library in Istanbul, shelfmark 1413. I have consulted the manuscript in Istanbul.
} 


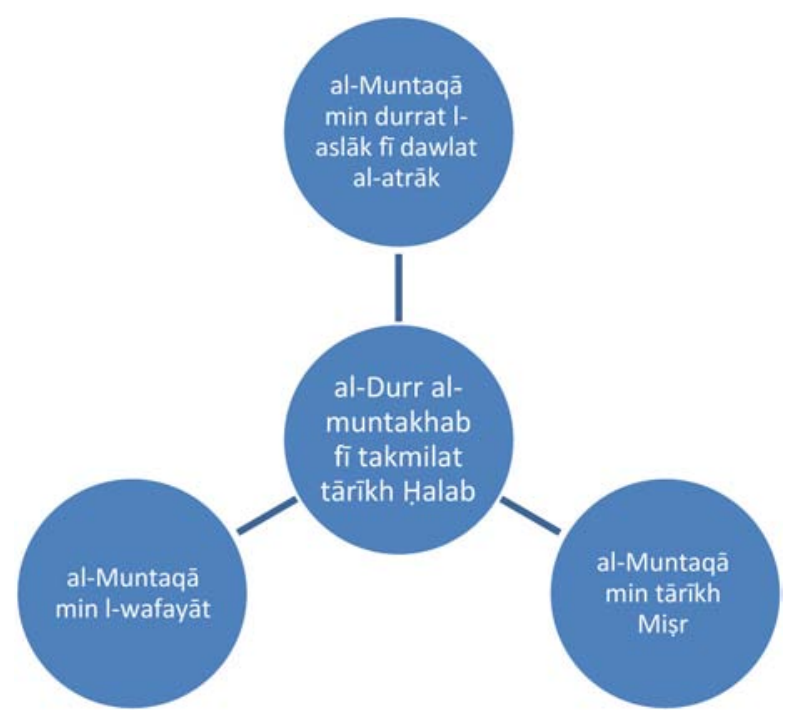

FIGURE 4.10 Selections by Ibn Khațîb al-Nāṣiryya that informed his al-Durr al-muntakhab

many others. This working method (of producing selections) was adopted by many 15th-century historians, like Ibn Khațîb al-Nāșiriyya, who made selections from historiographical works about the history of Aleppo and its elite in order to write his work al-Durr al-muntakhab fì takmilat tārïkh Halab. These selections were taken from several works, some of which have reached us as: 1. Durrat al-aslākfı́dawlat al-Atrāk of Ibn Ḥabīb al-Ḥalabī from which Ibn Khațīb al-Nāșiriyya selected some biographies and records of historical events; ${ }^{125} 2$. Tārīkh Mișr of Quțb al-Dīn al-Ḥalabīin from which some of the biographies and records of historical events were selected as well;;27 3 . al-Wafayāt of al-Irāqi from which Ibn Khațîb al-Nāșiriyya selected some biographies of the scholars of Aleppo. ${ }^{128}$ These three holographs were used by Ibn Khațîb al-Nāṣiriyya to write his work al-Durr al-muntakhab (see figure 4.10).

On the other hand, we can see that al-Maqrīzì used his selections from Ibn Muyassir's work Akhbār Mișr to write several works, such as Itti'äz al-ḥunafä

125 This work (titled Durrat al-aslāk) is still a manuscript in Staatsbibliothek zu Berlin under classmark (9724). However, after examining it, it turned out that this is rather a manuscript of Ibn Khațīb al-Nāṣiriyya's selections.

126 He is the historian Quṭb al-Dīn 'Abd al-Karīm b. 'Abd al-Nūr al-Ḥalabī (d. 735/1335). See al-Zarkalī, A`ām iv, 53 .

127 The manuscript of this work is held in the Library of Khalidi in Jerusalem under classmark (31).

128 Ibid. 


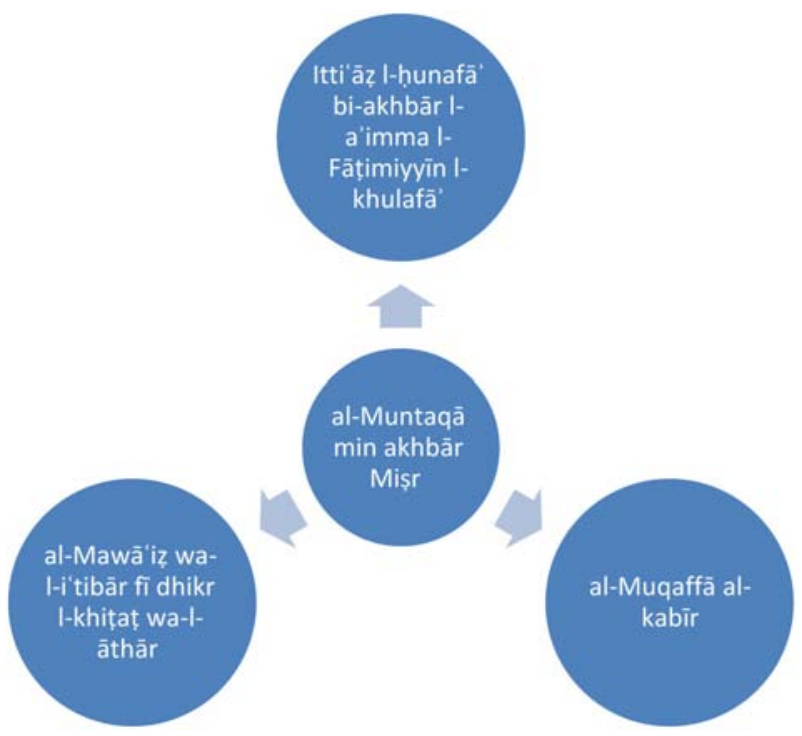

FIGURE 4.11 Muntaqā al-Maqrīzī used to inform his three mentioned works

bi-akhbār al-äimma al-Fäțimiyyīn al-khulafä, ${ }^{129}$ al-Muqaffā l-kabir, ${ }^{130}$ and alMawāiz wa-l-itibār fì dhikr l-khitațwa-l-āthār (see figure 4.11). ${ }^{131}$

Ibn Qādī Shuhba also wrote several selections that varied in size. Some of them were in several volumes, like his selections from Tärīkh al-Islām and al-Bidāya wa-l-nihāya, and others were written in just one volume. Noticeably, Ibn Qāọī Shuhba had a specific method of making these selections. For instance, when he wanted to write his book Tabaqāt al-Shäficyya, he made several notebooks of selections of biographies of Shāfi'i scholars from Durrat al-aslāk, Dhayl al-rawdatayn of Ibn Abī Shāma, Tārīkh al-Islām of al-Dhahabī, and Țabaqāt fuqahä'al-Yaman of Ibn al-Ja'dì.

Ibn Qādī Shuhba also used to make selections from voluminous works he did not seem to have a copy of in his personal library, like Tärïkh al-Isläm, al-Bidāya wa-l-nihāya, Tärïkh Ibn al-Furāt, and Tārīkh Ibn Duqmāq. Sometimes he made selections from the small works he did not need very often, like the biographies

129 The selections from Ibn Muyyasir that have been used in Itti 'äz al-hunafä’ are in al-Maqrīzī, Itticāz ii, 296; iii, 69, 71, 86 .

130 The selections from Ibn Muyyasir that have been used in Itticäz al-hunafă ${ }^{’}$ are in al-Maqrīzī, al-Muqaffā v, 89, 140, 300, 395, 431, 476, 505, 538, 684, 711; vi, 309 .

131 The selections from Ibn Muyyasir that have been used in Itti'äz al-hunafä' are in al-Maqrīzì, al-Khițat i, 159, 222, 254, 269; ii, 386, 405, 422, 45o, 452, 495, 529, 589, 6oo; iii, 51, 545, 727. With regard to the analysis of these working methods, I refer to F. Bauden's extensive and excellent work, who studied them in detail within the framework of the Maqriziana. 
of the Shāfici scholars from Ṭabaqāt fuqahäa al-Yaman ${ }^{132}$ and Dhayl al-'ibar ${ }^{133}$ of al-Husaynī. However, if a book was small or medium-sized and he needed it very often, he would rather copy it in full, like Ṭabaqāt al-Shāfíiyya al-wusțā'134 of al-Subkī and Kitāb al-Wafayāt $t^{135}$ of Jamāl al-Dīn al-Misallātì. On the other hand, if Ibn Qâdịi Shuhba had the book he needed as a reference in his library, he used to just make comments in its margins, without copying any part of it, as he did with Ṭabaqātal-fuqahä'al-kubrā ${ }^{136}$ of al-'Uthmānī and Durar al-'uqūd al-farìda ${ }^{137}$ of al-Maqrīzī.

Noticeably, when Ibn Qāḍi Shuhba wrote the selections for his work Ṭabaqāt al-Shäficiyya, he wrote each set of selections from each work in a separate notebook. However, this was not the case when he made a selection for his other works, as he used to combine selections from several works in one volume as he did with Tärīkh Ibn Duqmāq and Tärīkh Ibn al-Furät. Anyhow, in the following part, I will briefly discuss these selections and for which book he wrote them:

3.6.2.2.1 al-Muntaqā min al-ansāa $b^{138}$

This work consists of selections from Kitāb al-Ansāb of al-Sam'ānī. He used the selections from this book to write several works, such as Tabaqāt al-

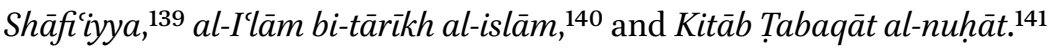

3.6.2.2.2 al-Muntaqā min tārīkh al-Iskandariyya ${ }^{142}$

This work consists of selections from al-Nuwayrì's book al-Ilmām bi-l-i'äm fimā jarat bihi al-ahkām wa-l-umūr al-maqdiyyāt fi wāqiat al-Iskandariyya. This Muntaqā was used in writing Ibn Qāḍī Shuhba's work Mukhtașar al-dhayl. ${ }^{143}$

132 The manuscript of this work is held in Staatsbibliothek zu Berlin under classmark (258).

133 The manuscript of this work is held in Chester Beatty Library under classmark (3151) (8097).

134 The manuscript of this work is held in Chester Beatty Library under classmark (4922).

135 The manuscript of this work is held in Bibliothèque nationale de France (BNF) under classmark (172) (263-9).

${ }_{13}$ The manuscript of this work is held in Sulaymanye library in Istanbul under classmark (159). There is an ownership statement of Ibn Qāọī Shuhba on this manuscript, and there are many comments of his in its margins.

137 The manuscript of this work is held in the collection of Gotha Research Library under classmark (1771). Ibn Qāọī Shuhba also commented in its margins.

${ }_{13} 8$ Badr al-Dīn b. Qāẹī Shuhba, Tarjamat 478.

139 See, for example, Ibn Qāẹī Shuhba, Ṭabaqāt i, 79, 121, 163.

140 See, for example, Ibn Qāḍī Shuhba, al-I ${ }^{\top} \bar{a} m$ (Morocco manuscript) i $24^{\mathrm{b}}, 42^{\mathrm{b}} ; \mathrm{ii} 3^{\mathrm{b}}, 6^{\mathrm{b}}$.

141 See for example. Ibn Qāḍī Shuhba, Ṭabaqāt al-nuhāh 72, 105, 129, 145, 188, 212-3, 25 o.

142 Badr al-Dīn b. Qāọī Shuhba, Tarjamat 478.

143 Ibn Qāḍī Shuhba, Tārīkh i, 136; ii, 77, 292, 309. 


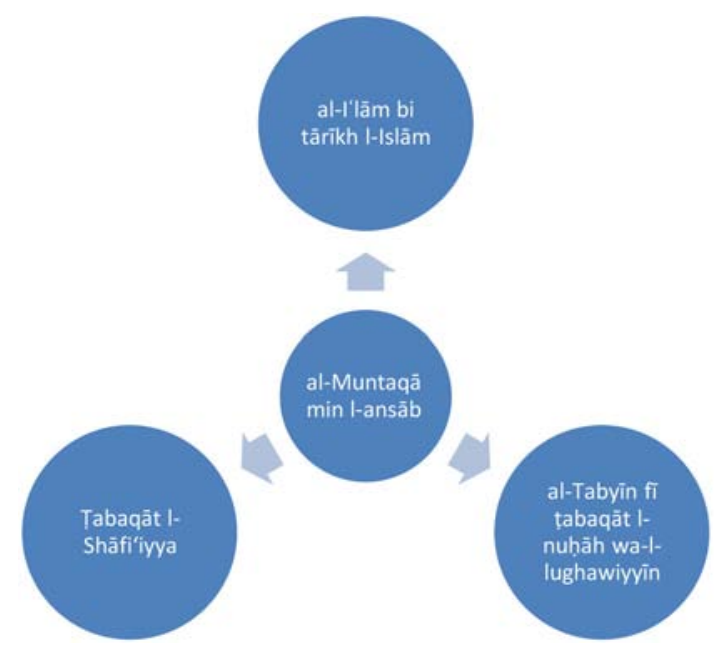

FIGURE 4.12 al-Muntaqā that informed Ibn Qāḍi Shuhba's three mentioned works

3.6.2.2.3 al-Muntaqā min tārīkh dimash $q^{144}$

This work consists of selections from Ibn 'Asākir's work Tärīkh dimashq. I must note that this muntaqā is different from his other work Tārīkh binā' madinat dimashq, as the former work consists of two volumes while the latter work is less than one volume. This muntaqā was used in writing Ibn Qāḍi Shuhba's works al-II àm bi tārīkh al-islām ${ }^{145}$ and Țabaqāt al-Shāficiyya. ${ }^{146}$

\subsubsection{4 al-Muntaqā min durrat al-aslāk}

This work consists of selections from Kitāb Durrat al-aslāk fi dawlat al-atrāk. To my knowledge, this work has never been mentioned in any of the studies of Ibn Qādīi Shuhba's career. However, I found an autograph manuscript of it in the library of the Bibliothèque Nationale de France. ${ }^{147}$ He used the selections from this book when he wrote several works, such as Mukhtașar al-dhayl, ${ }^{148}$ Tabaqät

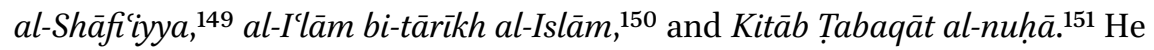
probably also used this muntaqā to write his books Dhayl al-tārïkh and Takmilat tārīkh Ibn Hijjji.

\footnotetext{
144 Ibn Qāọī Shuhba, Hayāt 479.

145 See, for example, Ibn Qāḍī Shuhba, al-I'lām (Morocco manuscript) i, 15 a 48 $8^{\mathrm{b}}, 49^{\mathrm{b}}$.

146 See, for example, Ibn Qāḍī Shuhba, Ṭabaqāt i, 114, 128, 140, 171, 217.

147 Under classmark (1721).

148 Ibn Qāạī Shuhba, Tärīkh ii, 69, 71, 73, 90, 137.

149 See, for example, Ibn Qāḍī Shuhba, Țabaqāt ii, 172-3, 182, 199.

150 See, for example, Ibn Qāụī Shuhba, I' $\bar{a} m$ (Turkey manuscript) $2^{\mathrm{b}}, 11^{\mathrm{b}}, 14^{\mathrm{b}}, 18^{\mathrm{a}}$.

151 See, for example, Ibn Qāạī Shuhba, Ṭabaqāt al-nuhāăh 95.
} 


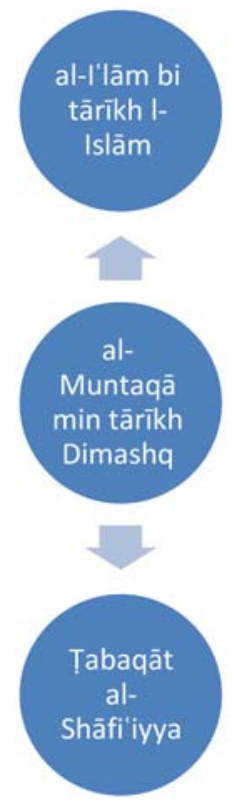

FIGURE 4.13

al-Muntaqā that informed Ibn Qāḍ̄i Shuhba's al-I'lām and Ṭabaqāt

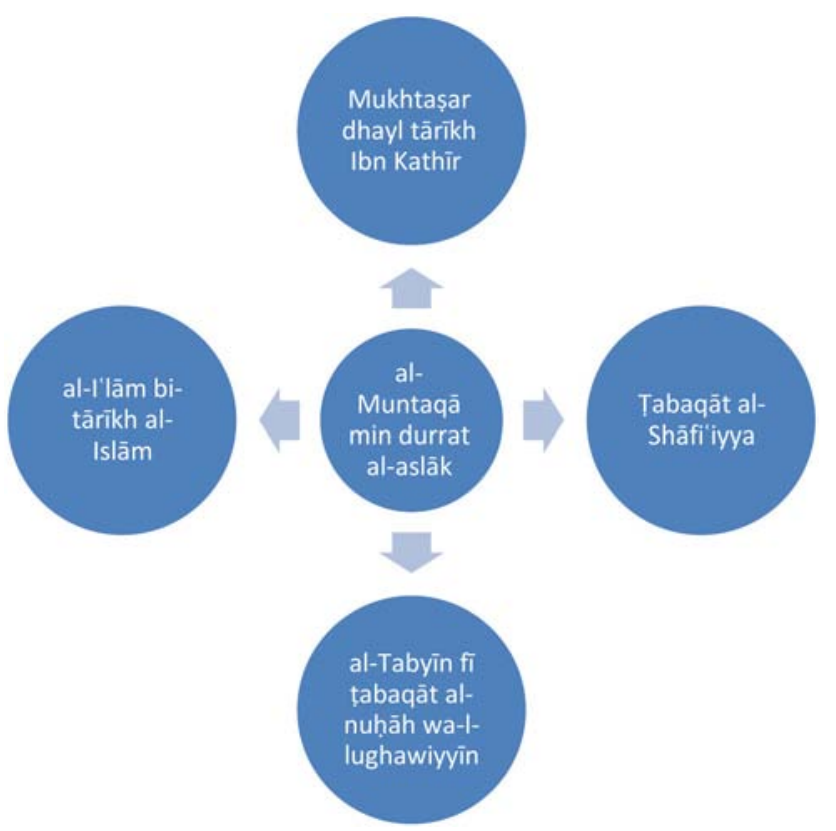

FIGURE 4.14 al-Muntaqā that informed Ibn Qāḍi Shuhba's four mentioned works 


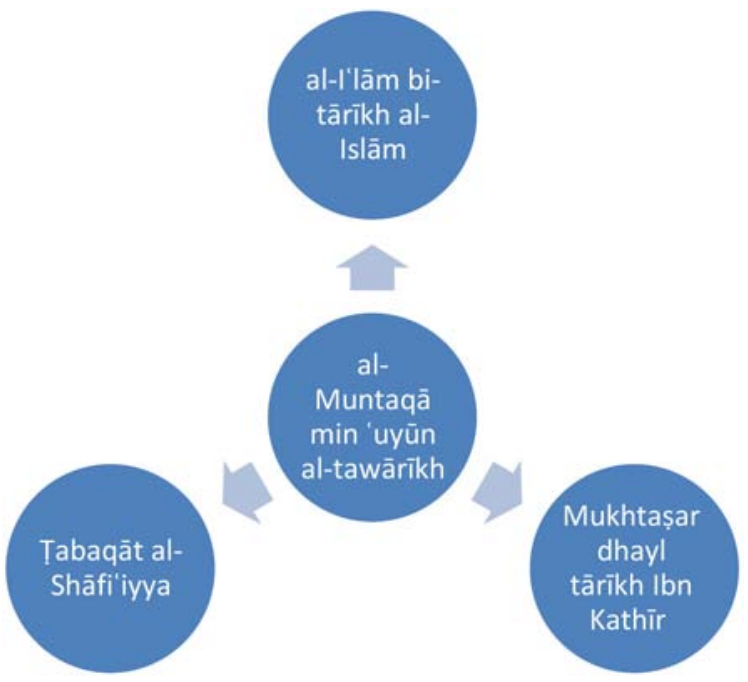

FIGURE 4.15 al-Muntaqā that informed Ibn Qāọ̄i Shuhba's three mentioned works

3.6.2.2.5 al-Muntaqā min 'uyūn al-tawārīkh

Ibn Shākir al-Kutubī's book 'Uyūn al-tawārīkh was quite important for Ibn Qāḍ̄ Shuhba, who used information from it in most of his historiographical writings. Most probably, Ibn Qāḍi Shuhba had some volumes of this work in his library, as I found his comments in the margins of a manuscript, which clearly indicate that he owned at least this manuscript. ${ }^{152} \mathrm{He}$ also wrote a muntaqa from the volumes he did not own, which was then used by Ibn Hajar as a source for his work al-Durar al-kāmina ${ }^{153}$ and by Ibn Qāḍi Shuhba himself in writing several works, such as al-II àm bi-tärïkh al-Isläm, ${ }^{154}$ Mukhtașar al-dhayl, ${ }^{155}$ and Tabaqāt al-Shāficiyya. ${ }^{156} \mathrm{He}$ probably also used this muntaqā when writing his books Dhayl al-tārīkh and Takmilat tārīkh Ibn Hijjīi.

152 This manuscript is held in the Library of the British Museum under classmark (OR. 3005). I am grateful to Benedikt Reier, who informed me of this manuscript.

153 Ibn Hajar, Durar ii, $15^{8}$.

154 I did not mention the places where Ibn Qāḍī Shuhba uses information from al-Muntaqa min 'uyūn al-tawārīkh in his work al-I läm, since the latter work is primarily based on the former work in addition to the histories of al-Dhahabī and Ibn Kathīr.

155 Ibn Qāḍi Shuhba, Tärīkh ii, 23, 39, 57, 95.

156 See, for example, Ibn Qāḍī Shuhba, Ṭabaqāt ii, 8o, 173, 215, 239, 263. 


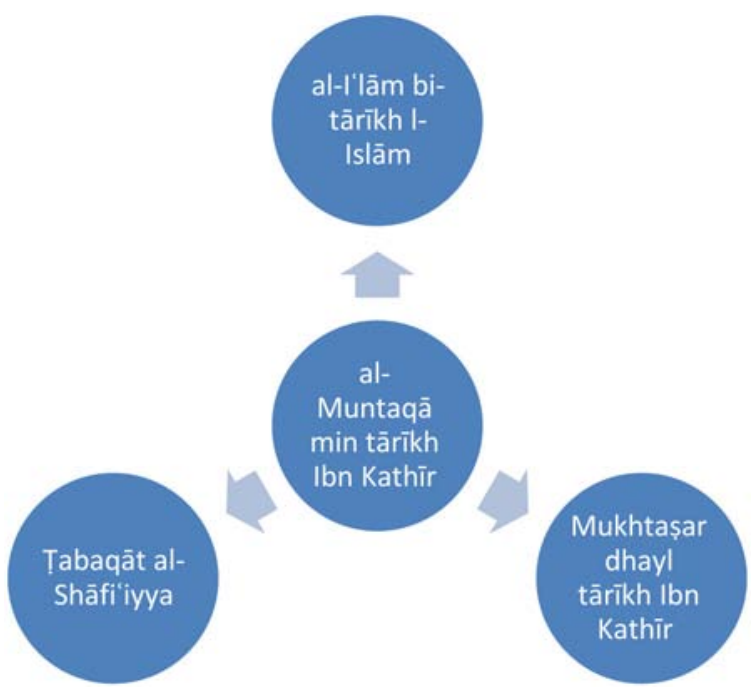

FIGURE 4.16 al-Muntaqā that informed Ibn Qāḍi Shuhba's three mentioned works

3.6.2.2.6 al-Muntaqā min mu'jam shuyūkh Ibn Rajab ${ }^{157}$

This book is a muntaqā from the book Mu'jam shuyūkh Ibn Rajab al-Hanbalī. He used this book as a source for his work Mukhtașar al-dhay $l^{158}$ and probably for his works Dhayl al-tārïkh and Takmilat tārïkh Ibn Hịji.

3.6.2.2.7 al-Muntaqā min tārīkh Ibn Kathīr

Ibn Qāḍī Shuhba wrote this muntaqā from Ibn Kathīr's work al-Bidāya wa-lnihāya. To my knowledge, this muntaqa has not been mentioned in any work about Ibn Qādī Shuhba. I found the manuscript of this work in the Library of Chester Beatty. It had no title, but after examining it, I found out that it was an autograph manuscript of Ibn Qāọī Shuhba, which contains a selection from alBidāya wa-l-nihāya. This muntaqā is probably one of many. Anyhow, the info in this selection was used in his works al-Ilām bi tärīkh al-Islāmm, ${ }^{159}$ Mukhtașar

157 This work was edited and printed in Kuwait, but attributed to a different author. However, after examining it, I found out through his handwriting that it was actually written by Ibn Qādīi Shuhba. The manuscript of this work is held in Yale University under classmark (292).

$15^{8}$ Ibn Qāḍī Shuhba, ii 23, 90, 252, 255, 280-1.

159 I did not mention the places where Ibn Qādị Shuhba uses information from the history of Ibn Kathīr in his work al-I'läm since the latter work is primarily based on the former work in addition to the histories of al-Dhahabī and Ibn Kutubī. 
al-dhayl, ${ }^{160}$ and Țabaqāt al-Shäfíiyya ${ }^{161}$ (and probably in Dhayl al-tärīkh and Takmilat tārīkh Ibn Hijjī as well).

\subsubsection{8 al-Muntaqā min tārīkh al-Islām}

Ibn Qāḍī Shuhba was quite interested in al-Dhahabī's working methodology and approach, as we can infer from Ibn Qādīi Shuhba's very frequent use of alDhahabī's works as sources for his historiographical writings. Ibn Qādīishuhba's interest was not limited to al-Dhahabī's fair copies (mubayyadāt), but he was also interested in al-Dhahabī's drafts and muntaqayāt; the latter was often used as a source for his works. I would actually suggest that Ibn Qāḍī Shuhba adopted al-Dhahabì's working method of using muntaqayāt as a source for his work, which further suggests Ibn Qāḍī Shuhba's interest in al-Dhahabīs works ${ }^{162}$ since when the former (in his work Mukhtașar al-dhayl) mentions the latter's works, almost 75 percent are historiographical works. Ibn Qādī Shuhba probably read these works, as he gave quite extensive descriptions of them in addition to a detailed description of al-Dhahabỉ's abridgements, such as Mukhtașar dhayl tārīkh Baghdād ${ }^{163}$ of Ibn al-Dubaythī and Mukhtașar tārīkh Nīsābūr ${ }^{164}$ of al-Hākim al-Nīsābūrī, which Ibn Qāḍī Shuhba probably used as sources for his works as well. Anyhow, Ibn Qāḍī Shuhba's muntaqā from tārīkh al-Islām was used as a source for his works al-I Iām bi-tärīkh al-Islām, ${ }^{165}$ Tabaqāt alShāficiyya, ${ }^{166}$ and Tabaqāt al-nuhāah. ${ }^{167}$

\subsubsection{9 al-Muntaqā min mujam al-mukhtașș ${ }^{168}$}

This book is a muntaqa from al-Dhahabī's work Mujam al-mukhtașs. Most probably, he wrote this work to use in his work Dhayl al-tärīkh as he referred to it in more than 100 places in Mukhtașar al-tārīkh. ${ }^{169}$ On the other hand, he also used this muntaqa in other historiographical works, such as al-I ${ }^{\top} \bar{a} m$

\footnotetext{
16o Ibn Qāḍī Shuhba, Tārīkh i, 122, 126, 140, 155 .

161 See, for example, Ibn Qāḍī Shuhba, Țabaqāt ii, 6, 52, 75, 105.

162 Ibn Qāọī Shuhba, Tārīkh 534.

163 See, for example, Ibn Qāạī Shuhba, Țabaqāt ii, 25, 40, 46, 48; Ṭabaqāt al-nuḥ̂āh 36, 46, 59.

164 See, for example, Ibn Qāụī Shuhba, Țabaqāt i, 63, 71, 91, 99; Ṭabaqāat al-nuhạāh 181, 288.

165 I did not mention the places where Ibn Qāḍī Shuhba uses information from Tārīkh alIslām in his work al-I lām since the latter work is primarily based on the former work (in addition to the histories of Ibn Kathīr and al-Kutubī).

166 See, for example, Ibn Qāọī Shuhba, Ṭabaqāt i, 63-5, 70, 73 .

167 See, for example, Ibn Qāḍī Shuhba, Ṭabaqāt al-nuḥāh 23, 49, 53, 55, 77 .

168 The manuscript of this work is held in Maktabat al-awqāf al-āmma fī Baghdād under classmark 2841.

169 See, for example, Ibn Qāḍī Shuhba, Tārīkh i, 141-2, 164, 171, 197.
} 


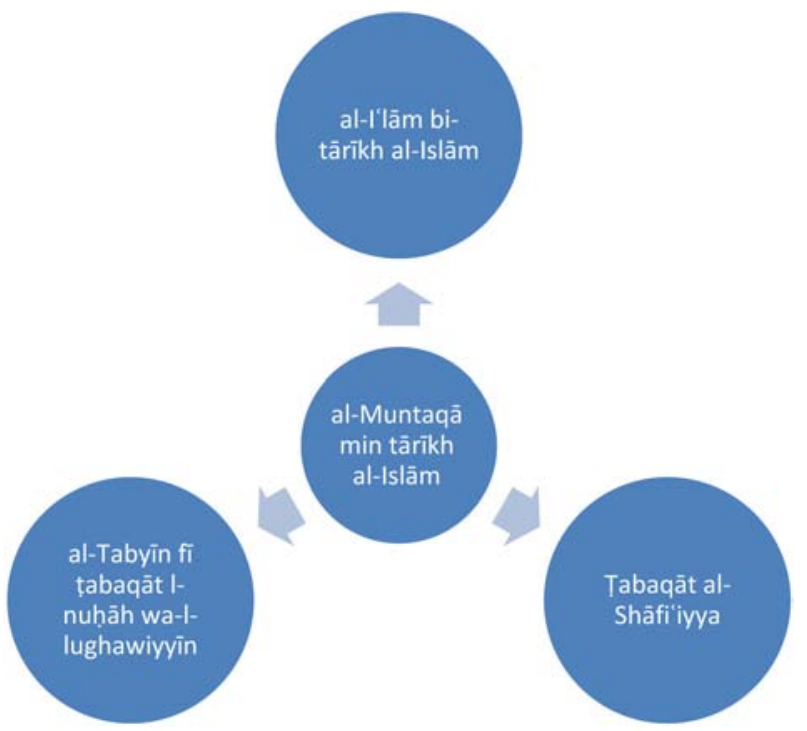

FIGURE 4.17 al-Muntaqā that informed Ibn Qāḍī Shuhba's three mentioned works

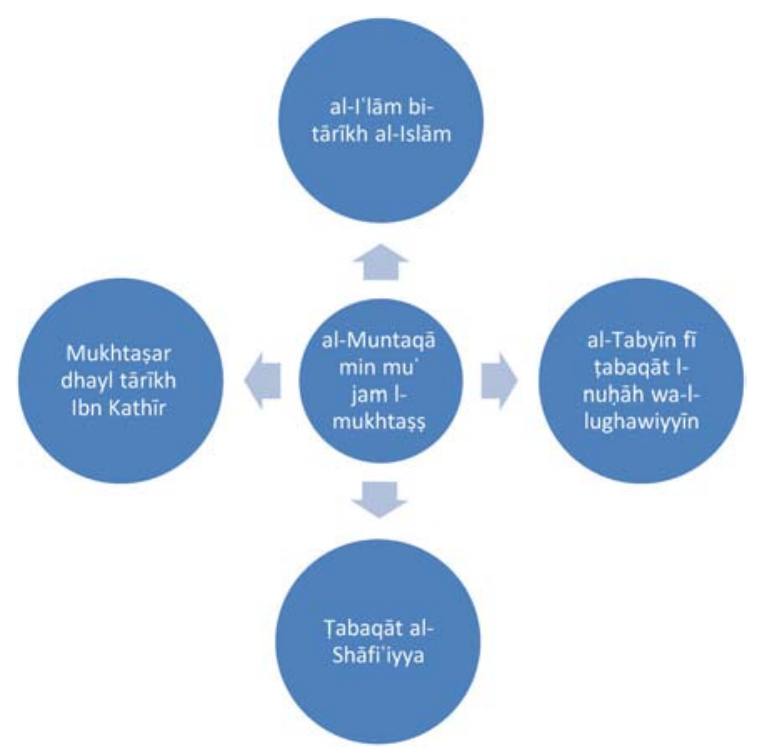

FIGURE 4.18 al-Muntaqā that informed Ibn Qāḍi Shuhba's

four mentioned works 


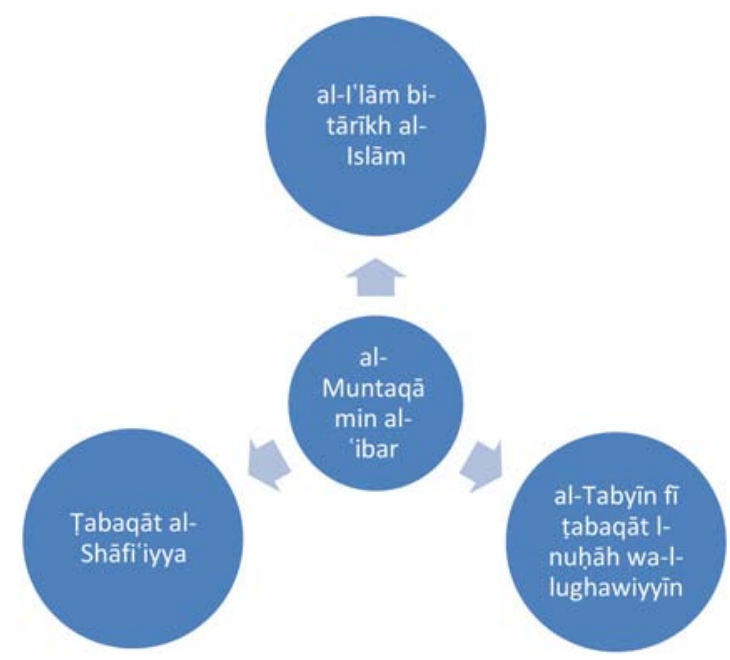

FIGURE 4.19 al-Muntaqā that informed Ibn Qāḍī Shuhba's three mentioned works

bi-tārīkh al-Islām, ${ }^{170}$ Ṭabaqāt al-Shāficiyya, and Ṭabaqāt al-nuhāa, ${ }^{171}$ and most likely in Takmilat tārīkh Ibn Hijjiı as well.

3.6.2.2.10 al-Muntaqā min al- ibar ${ }^{172}$

This book is a muntaqā from the book of al-Dhahabī's work Kitāb al-Tbar. He used this muntaqā in other historiographical works, like al-I İamm bi-tārīkh alislām, ${ }^{173}$ Ṭabaqāt al-Shāfíiyya, ${ }^{174}$ and Ṭabaqāt al-nuhă. ${ }^{175}$

\subsection{1 al-Muntaqā min tārīkh Ibn Duqmā $\quad$ a ${ }^{176}$}

This notebook is a muntaqa a from Ibn Duqmāq's work Nuzhat al-anām fì tārīkh al-Islām. Most probably, the last volume of this work was sent to Ibn Qādī Shuhba by Ibn Hajar. However, I can say with certainty that this muntaqa was written specifically for Dhayl al-tärīkh as he used it neither in al-I'läm

170 See, for example, Ibn Qāọī Shuhba, I'ām (Suleymaniye Library manuscript) $3^{\mathrm{a}}, 3^{\mathrm{b}}, 5^{\mathrm{b}}, 7^{\mathrm{a}}$, $134^{\mathrm{a}}, 140^{\mathrm{b}}$.

171 See, for example, Ibn Qāḍī Shuhba, Ṭabaqāt al-nuhạh 289.

172 The manuscript of this work is held in the British Museum under classmark (Or. 3006).

173 See, for example, Ibn Qāḍī Shuhba, I $I^{\prime a} m$ (Suleymaniye Library manuscript) $23^{\mathrm{b}}, 35^{\mathrm{b}}, 36^{\mathrm{a}}$, $38^{\mathrm{b}}, 39^{\mathrm{a}}$.

174 See, for example, Ibn Qāḍī Shuhba, Țabaqāt i, 283; ii, 136, 214, 26 o.

175 See, for example, Ibn Qāḍī Shuhba, Tabaqāt al-nuhāăh 89.

${ }_{17} 6$ The manuscript of this work is held in the Chester Beatty Library under classmark (4125). 


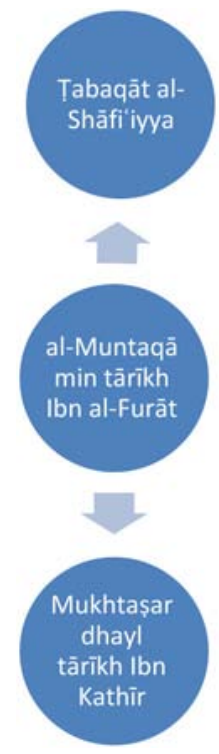

FIGURE 4.20

al-Muntaqā that informed Ibn Qāḍī Shuhba's Tabaqāt al-Shāfi iyya and Mukhtașar al-dhayl

bi-tārīkh al-islām or Ṭabaqāt al-Shāficiyya, but it was extensively used in Mukhtașar al-dhayl. ${ }^{177}$

\subsection{2 al-Muntaqā min tārīkh Ibn al-Furāt ${ }^{178}$}

This notebook contains selections from Tārīkh b. al-Furāt of historical events and biographies from the 8th/14th century. The original work is in four volumes that were sent to Ibn Qāḍī Shuhba by Ibn Ḥajar one by one (i.e., once Ibn Qàḍī Shuhba finished taking the selections from one of the volumes, he would send it back to Ibn Hajar and receive the following volume). ${ }^{179}$ Most probably, this muntaq $\bar{a}$ was originally in four notebooks, which were written to be used for his work Dhayl al-tārïkh, but they were also used in Mukhtașar al-dhay/180 and Tabaqāt al-Shäficiyya. ${ }^{181}$

\subsection{3 al-Muntaqā min al-mudhayyal 'alā-l-rawdatayn ${ }^{182}$}

This notebook contains selections of the biographies of Shāfi'i scholars from Ibn Abī Shāma's work al-Mudhayyal 'alā-l-rawdatayn. Certainly, this muntaqā

177 See, for example, Ibn Qāạī Shuhba, Tārīkh ii, 486; iii, 130, 162, 366, 554, 556.

178 The manuscript of this work is held in the Chester Beatty Library under classmark (4125).

179 Ibn Qāḍī Shuhba, Tārīkh iv, 455.

180 Ibid., Tārīkh ii, 235, 332.

181 Ibid., Tabaqāt iv, 5. With regard to the notes of Ibn Qāḍī Shuhba, see Reisman, Holograph.

182 The manuscript of this work is held in the Amirton University under classmark $(203 \mathrm{H})$. 


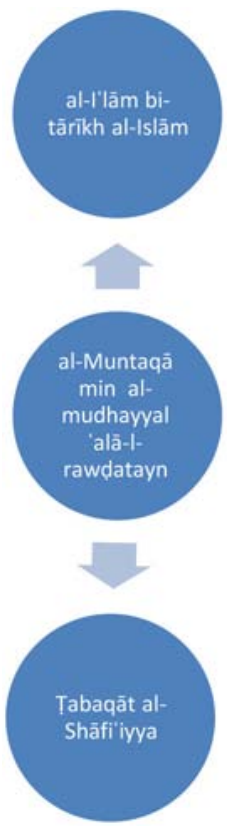

FIGURE 4.21

al-Muntaqā that informed Ibn Qāḍī Shuhba's Ṭabaqāt al-Shāficiyya and al-İ̄ām bi-tārīkh al-Islām

was meant to be used in his work Tabaqāt al-Shāficiyya. ${ }^{183}$ However, it was also used in his book al-I'lām bi-tārīkh al-Islām. ${ }^{184}$

\subsection{4 al-Muntaqā min țabaqāt fuqahā’ al-Yaman ${ }^{185}$}

This notebook is a muntaqā from Ibn al-Ja'dī al-Yamanı̄'s work Ṭabaqāt fuqahā' al-Yaman. Ibn Qāḍì Shuhba mainly selected the biographies of Shāfíì scholars in order to use them in his work Tabaqāt al-Shāfi iyya. ${ }^{186}$

\subsection{5 al-Muntaqā min mu'jam shuyūkh Ibn Rajab}

This notebook contains selections from Mu'jam shuyūkh Shihāb al-Dīn b. Rajab. Ibn Qāọi Shuhba, however, rearranged the entries of the Mujam by annals instead of listing them alphabetically, as tends to be the case for most of the works of Ma'äjam al-Shuyūkh. I can say with certainty that this muntaqā was written to be used to write his work Dhayl al-tārīkh since both works started with the year 741 and that the information from al-Muntaqā was referred to more than 100 times in his book Mukhtașar dhayl tärīkh Ibn Kathïr. ${ }^{187}$ In con-

183 Ibn Qāḍī Shuhba, Ṭabaqāt ii, 55, 57, 66, 68, 70.

184 See, for example, Ibn Qāọī Shuhba, al-Ilām (Suleymaniye Library manuscript) $2^{\mathrm{b}}, 3^{\mathrm{a}}, 4^{\mathrm{a}}$, $4^{\mathrm{b}}, 5^{\mathrm{a}}$.

185 The manuscript of this work is held in Staatsbibliothek zu Berlin under classmark (258).

186 Ibn Qāḍī Shuhba, Țabaqāt i, 282, 305.

187 See, for example, Ibn Qāḍī Shuhba, Tārīkh 141, 16o, 169, 176, 177. 


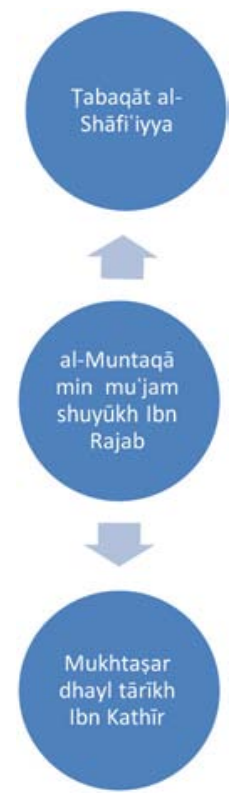

FIGURE 4.22

al-Muntaqā that informed Ibn Qāḍi Shuhba's Ṭabaqāt al-Shāfi ìyya and Mukhtașar al-dhayl

trast, this muntaqā was used just once in his other work, Ṭabaqāt alShäficyya, ${ }^{188}$ which clearly shows that he made these selections for writing his work Dhayl al-tärïkh, and he also might have used them in his writing of Takmilat tārīkh Ibn Hịjji.

3.6.2.2.16 al-Muntaqā min țabaqāt al-Hanafìya

Badr al-Dīn b. Qāḍī Shuhba mentioned that his father wrote a biographical dictionary of Hanafì scholars arranged by generation (Tabaqāt). However, I find this very unlikely, although he might have written a muntaqa from the Ḥanafi work Tabaqāt to use as a source for his historiographical works. In fact, Ibn Qāḍi Shuhba frequently quoted the unnamed H̦anafị Țabaqāt in his work al-Ilām bitārikkh al-Isläm. After examining these quotes, I found out that they were taken from al-Qurashī's work al-Jawāhir al-muḍ̂̀a fì țabaqāt al-Hanafìya. ${ }^{189}$

3.6.2.2.17 al-Muntaqā min nukhbat al-dahr fì 'ajā'ib al-barr wa-l-bahr ${ }^{190}$ This notebook is a muntaqa from Ibn Shaykh Hitțīn's work Nukhbat al-dahr fi 'ajāib al-barr wa-l-bahrr. I am not sure exactly in which book this muntaqā was used, but it was most likely used in al-Ilām bi-tārīkh al-Islām.

188 Ibid., Țabaqāt iii, 14 .

189 See, for example, Ibn Qāḍī Shuhba, I'lām (Suleymaniye Library manuscript) $3 \mathrm{o}^{\mathrm{a}}$.

190 Badr al-Dīn b. Qāḍī Shuhba, Hayāt 478. 


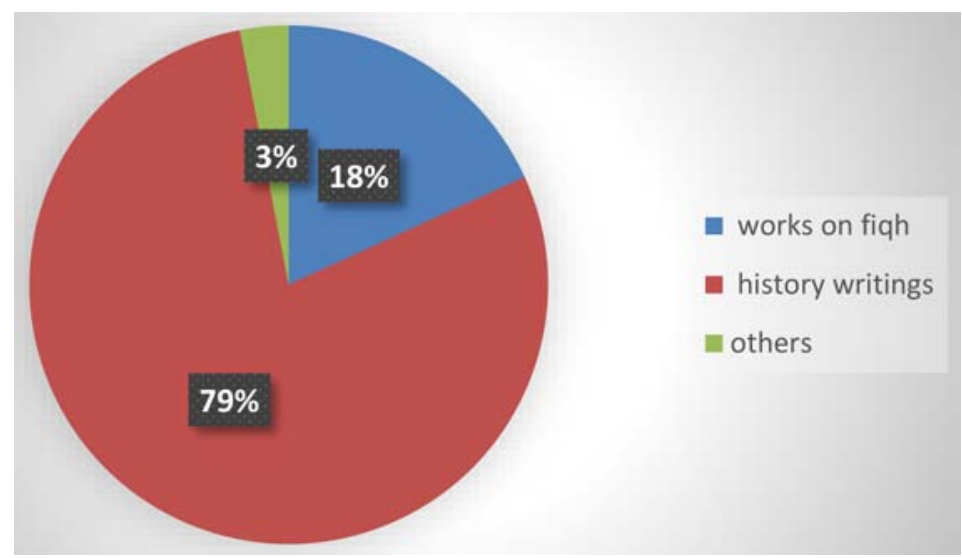

FIGURE 4.23Ibn Qāḍī Shuhba's works

\section{$4 \quad$ Epilogue}

We can clearly notice that Ibn Qāḍi Shuhba spent much of his career actively engaging with and writing historiographical works, which, as I will further clarify below, constituted a considerable portion of his total scholarly production. This shows that he was as much a historian as he was a faqih. However, in scholarly circles, he was generally regarded as a faqih because most of his historiographical works remained drafts circulating between the limited circles of his students, Damascene colleagues, and the students of his son Badr al-Dīn. ${ }^{191}$

The pie chart shows that $79 \%$ of Ibn Qāḍi Shuhba's total literary production are historiographic works.

A closer look at his only work that deals with the history of Islam (i.e., alI'lām bi-tārīkh al-Islām) reveals a striking peculiarity: his work avoids dealing with an important section of Islamic history, which witnessed the formation of the Shicites sects. Neglecting such a significant era in Islamic history sheds light on his approach to Islamic history and the underlying motives that influenced his historiographical works.

Also, he seems to have tried to conceal or obscure his Shicite family origin. As mentioned above, one of his older relatives, the chief of the Syrian chancery Shams al-Dīn, was actually the one who informed al-Ṣafại that the Ibn Qāọī Shuhba family descended from Banū Ghāḍira. Interestingly, Taqī al-Dīn b. Qāọi Shuhba copied most of the information about the roots of his family from

191 Only two works of Ibn Qāḍi Shuhba were made fair copies (mubayyḍ̣āt) of Ṭabaqāt alShäfïiyya and Mukhtașar dhayl al-tārīkh. 
al-Ṣafạī and Ibn Ḥabīb, ${ }^{192}$ but he omitted the part that links his family to the alGhādiriyya, without giving any justification for his choice. I would suggest that Taqi al-Dīn probably tried to obscure that his ancestors were Shi ites. I believe his reluctance to reveal this fact was due to his fear that this might have negative consequences for his sons, who took over his position as qădiss. I must mention that during Ibn Qāḍi Shuhba's era, the status of Shi ites in Syro-Egyptian society was ambivalent since they did not suffer from systemized oppression. However, I cannot find any evidence to suggests that Shi'ites were appointed in governmental positions. ${ }^{193}$ Of course, these initial thoughts and assumptions need further research. But I hope that I have shown in this introductory article that Ibn Qāḍi Shuhba is certainly an important figure and significant historian in the intellectual history of the Mamluk period who needs further attention and study.

\section{Bibliography}

\section{Manuscripts}

Ibn Ḥabīb al-Ḥalabī, Durrat al-asläkfi dawlat al-Atrāk, Library of the Mother of Sultan Mehmet Khan 233 .

Ibn Qāạī Shuhba, al-IIām bi-tārìkh al-Islām, 4 vols: 2 vols. al-Khizāna al-'Āmma Library 94, al-Rabāț; 1 vol. Sulaymanye library 1403, Istanbul; 1 vol. Yeni Cami library 864, Istanbul.

Ibn Qāḍī Shuhba, al-Muntaqā min al-ibar, British Library London 3006.

Ibn Qāạī Shuhba, al-Muntaqā min mújam al-mukhtașs, al-Awqāf Library Baghdad 2841. Ibn Qāḍī Shuhba, al-Muntaqā min durrat al-aslāk, Bibliothèque Nationale France 1721. Ibn Qāạī Shuhba, al-Muntaqā min tārīkh dimashq, Rashīd Afandī Library Istanbul 640. Ibn Qādī Shuhba, al-Muntaqā min tārīkh Ibn Duqmāq, Chester Beatty Library Dublin 4125.

Ibn Qādī Shuhba, al-Muntaqā min tārīkh Ibn al-Furät, Chester Beatty Library Dublin 4125 .

Ibn Qādị Shuhba, Dhayl 'alā tārīkh ibn Kathìr, 2 vols.: 1 vol. Gotha Library 1574; 1 vol. India Office Library 3805 . al-Ṣafadī, al-Tadhkira, Gotha Library 2140-1.

192 Ibn Qāḍī Shuhba, Tārīkh ii, 197.

193 For further information on the history of the Shica and Shicites at that period, see Winter, Shams al-Din. 


\section{Primary Sources}

al-Balādhurī, Ansāb al-ashrāf, eds. S. Zakkār and R. al-Zarkalī, 13 vols., Beirut 1996. al-Bașrawī, Tārīkh al-Bașrawī, ed. A. al-Ulabī, Damascus 1988.

al-Dhahabī, al-Mukhtaṣar al-muḥtāj ilayhi min tārīkh Ibn al-Dubaythī, ed. M. Jawād, 2 vols., Baghdad 1951.

al-Dhahabī, Tārīkh al-Islām wa-wafayāt al-mashāhīrwa-l-a'lām, ed. B.'A. Ma'rūf, 17 vols.,

Beirut 2003.

al-Dīnurī, Akhbār al-țuwāl, ed. J. al-Shayyāl, Cairo 1960.

al-Ghazzì, Bahjat al-nāzirīn ilā tarājim al-muta’akhkhirīn min al-Shāfíiyya al-bārīìn, ed.

'A.M. al-Kandarī, Beirut 2000.

Hājī Khalīfa, Kashf al-žunūn 'an asāmī al-kutub wa-l-funūn, ed. M. Sharaf al-Dīn, 2 vols., Baghdad 1941.

Ḥājī Khalīfa, Sullam al-wuṣūl ilā țabaqāt al-fuḥūl, ed. M. al-Arnā'ūṭ, 6 vols., Istanbul 2010. al-Hamawī, Mujam al-buldān, n.e., 7 vols., Beirut 1993.

Ibn al-'Āqūlī, al-Dirāya fìmárifat al-riwāya, ed. Q. al-Sāmarrā'̄̄, Riyadh 2016.

Ibn 'Asākir, Tārīkh madīnat Dimashq, ed. M. al-Amrāwī and A. Shīrī, 8 o vols., Damascus 1995 .

Ibn Aybak, al-Tarājim al-jalīla al-jaliyya wa-l-ašyāhh al-'aaliya al-'aliyya, ed. T. Sabraa, 2 vols., Göttingen Bonn 2017.

Ibn al-Dubaythī, Dhayl tārīkh Madīnat al-Salām, ed. B.A. Ma'rūf, 5 vols., Beirut 2006. Ibn Ḥabīb, Mukhtalaf al-qabāil wa-mu’talafihā, ed. I. al-Ibyārī, Cairo 1981.

Ibn Ḥajar, al-Durar al-Kāmina fí a yān al-mỉa al-thāmina, eds. Ḥ. al-Nadwī et al., 4 vols., India 193 .

Ibn Ḥajar, Inbǟ' al-ghumr bi-anbā’ al-umr, ed. H. Habashī, 4 vols., Cairo 1969-98.

Ibn Ḥajar, al-Ișāba fì tamyı̄z al-ṣahāāba, ed. 'A.M. al-Bajāwī, 8vols., Beirut 1992.

Ibn Hijjīi, Tärīkh Ibn Hijjī, ed. 'A.M. al-Kandarī, 2 vols., Beirut 2003.

Ibn al-Ḥimṣī, Hawādith al-zamān wa-wafayāt al-shuyūkh wa-l-aqrān, ed. 'A. Harfūsh, Beirut 2000.

Ibn al-Jawzī, al-Muntažim fì tārīkh al-mulūk wa-l-umam, ed. M.'A. 'Ațā., 19 vols., Beirut 1992.

Ibn al-Jazarī, Tārīkh ḥawādith al-zamān wa-anbā̄uhu wa-wafayāt al-akābir wa-l-ayā̄n min abnä̀ihi, ed. 'U.'A. al-Tadmurī, 3 vols., Sidon 1998.

Ibn Kathīr, al-Bidāya wa-l-nihāya, ed. 'A.b. 'Abd al-Muhsin al-Turkī, 21 vols., Cairo 1997. Ibn Khațīb al-Nāṣiriyya, al-Muntaqā min Durrat al-aslāk fì dawlat al-Atrāk, ed. A. Zakkār, Damascus 1999.

Ibn al-Maghāzilī, Manāqib 'Alī b. Abì Ṭālib 'alayhi al-salām, ed. A.'A. Turkī, Sanaa 2003. Ibn Mandah, al-Mustakhrajat min kutub al-nās, ed. Ā. Șabrī, 3 vols., Bahrain 2010. Ibn al-Misallātī, Wafayāt, ed. T. Sabraa, Göttingen Bonn (forthcoming). al-Nu'aymī, al-Dāris fi tārīkh al-madāris, ed. J. al-Ḥusaynī, 2 vols., Damascus 1948-51. Ibn Qāẹī Shuhba, Ṭabaqāt al-nuḥāh wa-l-lughawiyyīn, ed. M. Ghayāḍ, Najaf 1974. 
Ibn Qāḍī Shuhba, Tārīkh Ibn Qāḍ̄ Shuhba, ed. 'A. Darwīsh, 4 vols., Damascus 1977-97. Ibn Qāḍī Shuhba, Tarjamat Ibn Qādì Shuhba, ed. A. Darwīsh, in Majma al-Lugha alArabiyya bi-Dimashq 58/3 (1983), 457-500.

Ibn Qāḍī Shuhba, Ṭabaqāt al-Shāfíiyya, ed. 'A. Khān, 4 vols., Beirut 1986.

Ibn Qāẹī Shuhba, Manāqib al-Imām al-Shāfì̃ wa-țabaqāt aṣhābihi min Tārīkh al-Islām lil-Hāfiz Abī 'Abd Allāh al-Dhahab̄i, ed. 'A.F. Harfūsh, Damascus 2003.

Ibn Qāọī Shuhba, al-Muntaqā min Mujam Shuyūkh Aḥmad ibn Rajab al-Hanbalī, ed.

'A.M. al-Kandarī, Kuwait 2006.

Ibn Taghrībirdī, al-Nujūm al-zāhira, eds. M. Ramzī et al., Cairo 1929-20oo.

Ibn Ṭawq, al-Tå̀̄q: Yawmiyyāt Shihāb al-Dìn Aḥmad b. Ṭawq, ed. J. al-Muhājir, 4 vols., Damascus 2000.

Ibn Ṭūlūn, al-Thaghr al-bassām, ed. Ș. al-Munajjid, Damascus 1956.

Ibn Ṭūlūn, Mufākahat al-khillān fi ḥawādith al-zamān, ed. K. al-Manșūr, Beirut 1998.

Ibn Ṭūlūn, Mut'at al-adhhān min al-tamattu' bi-l-iqrān, ed. A.U. al-Mawșili, 2 vols., Beirut 1999.

Ibn Wāṣil, Mufarrij al-Kurūb fì akhbār Banī Ayyūb, ed. J. al-Shayyāl, 5 vols., Cairo 195377 .

al-Maqrīzī, al-Sulūk li-márifat duwal al-mulūk, ed. M. Ziyādah and S. As̄hūr, 8 vols., Cairo $1956-72$.

al-Maqrīzì, al-Muntaqā min akhbār Mișr, ed. A.F. Sayyid, Cairo 1981.

al-Maqrīzì, al-Muqaffā al-kabīr, ed. M. al-Ya'lāwī, 8 vols., Beirut 1991.

al-Maqrīzī, Itti 'āz al-hunafă’ bi-akhbār al-a'imma al-Fātimiyyīn al-khulafä', ed. J. al-

Shayyāl, 3 vols., Cairo 1996.

al-Maqrīzī, al-Mawā̄iz wa-l-itibār fı dhikr al-khițaț wa-l-āthār, ed. A.F. Sayyid, 5 vols., London 2002-4.

al-Mazzī, Tahdhīb al-kamāl, ed. B.'A. Márūf, 35 vols., Beirut 1980.

al-Najāshī, Rijāl al-najāshī, n.e., Beirut 2010.

Nașr b. Muzāḥim, Waq'it Șiffìn, ed. 'A. Hārūn, Cairo 1962.

al-Qushayrī, Tārīkh al-Raqqa, ed. I. Ṣāliḥ, Damascus 1998.

al-Ṣafadī, A'yān al-'aṣr wa-a'wān al-nașr, eds. A. Abū Zayd et al., 6 vols., Damascus 1998. al-Suyūṭī, Naẓm, al-'Iqyān fí a'yān al-a'yān, ed. F. Hịttī, New York 1927.

al-Ṭabarī, M., Tārīkh al-Ṭabarī: Tārīkh al-rusul wa-l-mulūk, ed. M.'A. Ibrāhīm, 11 vols., Cairo 1960.

al-Zarkālī, al-A'̄ām: Qāmūs tarājim li-ashhar al-rijāl wa-l-nisā̄ min al-Arab wa-l-

Musta'ribin wa-l-mustashriqin, n.e., 8 vols., Beirut 2002.

\section{Secondary Sources}

Berkey, J., The formation of Islam: Religion and society in the Near East, 600-1800, Cambridge 2003 .

Dussaud, R., Les Arabes en Syrie, Paris 1955. 
Jaques, K.R., Authority, conflict and the transmission of diversity in medieval Islamic law, Leiden and Boston 2006.

Jawād, M., Mawsū'at al-'atabāt al-muqaddasah, 12 vols., Beirut 1987.

Massoud, S., Ibn Hijji, in $E I^{3}$.

Massoud, S., The chronicles and annalistic sources of the early Mamluk Circassian period, Leiden 2007.

Reisman, D.C., A holograph Ms of Ibn Qāḍī Shuhbah's “Dhayl," in MSR 2 (1998), 19-49. Winter, S., Shams al-Din Muhammad ibn Makki "al-Shahid al-Awwal" (d. 1384) and the Shi'ah of Syria, in MSR 3 (1999), 149-82. 